\title{
Environmental Emissions Nonenergy Benefits Working Paper: ARRA Period
}

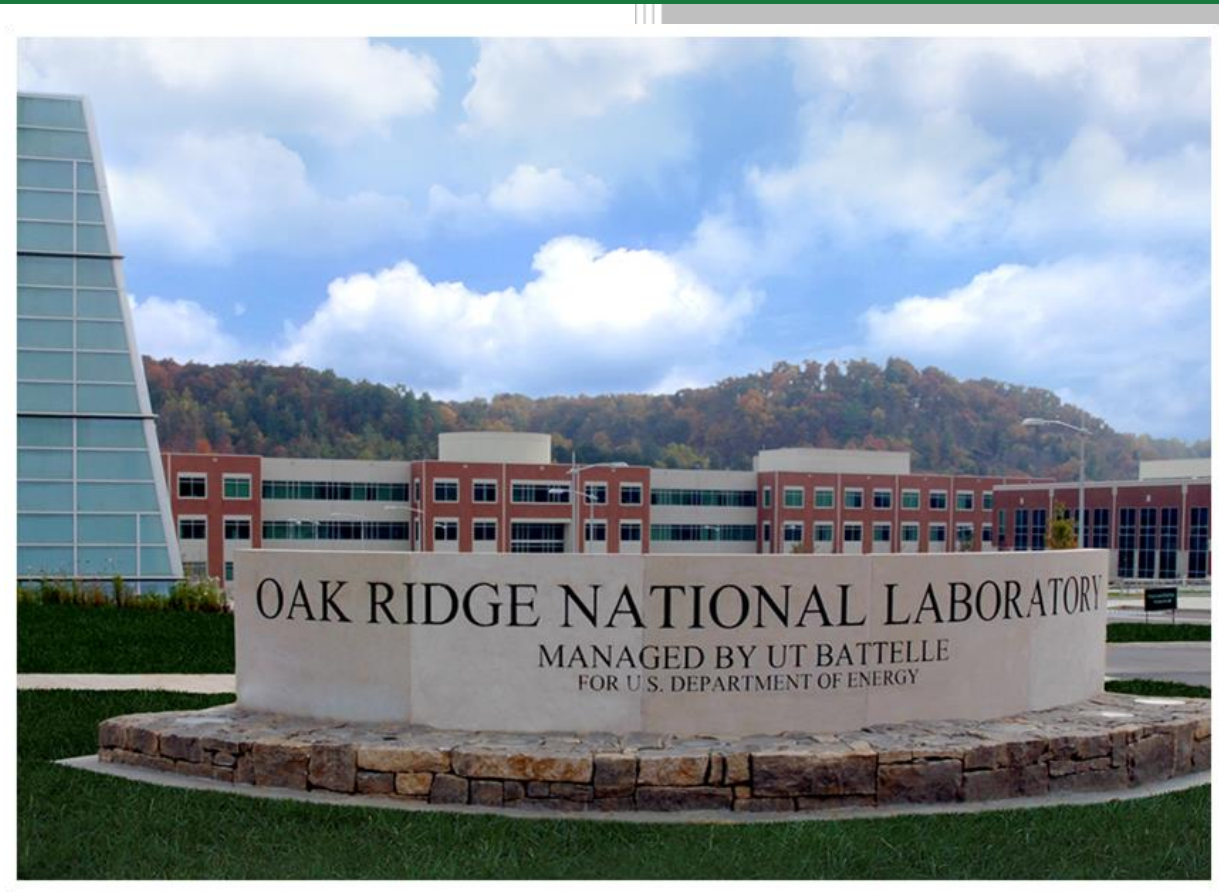

Approved for public release: distribution is unlimited.
David Carroll

Daniel Bausch

March 2015 


\title{
DOCUMENT AVAILABILITY
}

Reports produced after January 1, 1996, are generally available free via US Department of Energy (DOE) SciTech Connect.

Website http://www.osti.gov/scitech/

Reports produced before January 1, 1996, may be purchased by members of the public from the following source:

\author{
National Technical Information Service \\ 5285 Port Royal Road \\ Springfield, VA 22161 \\ Telephone 703-605-6000 (1-800-553-6847) \\ TDD 703-487-4639 \\ Fax 703-605-6900 \\ E-mail info@ntis.gov \\ Website http://www.ntis.gov/help/ordermethods.aspx
}

Reports are available to DOE employees, DOE contractors, Energy Technology Data Exchange representatives, and International Nuclear Information System representatives from the following source:

Office of Scientific and Technical Information

PO Box 62

Oak Ridge, TN 37831

Telephone 865-576-8401

Fax 865-576-5728

E-mail reports@osti.gov

Website http://www.osti.gov/contact.html

This report was prepared as an account of work sponsored by an agency of the United States Government. Neither the United States Government nor any agency thereof, nor any of their employees, makes any warranty, express or implied, or assumes any legal liability or responsibility for the accuracy, completeness, or usefulness of any information, apparatus, product, or process disclosed, or represents that its use would not infringe privately owned rights. Reference herein to any specific commercial product, process, or service by trade name, trademark, manufacturer, or otherwise, does not necessarily constitute or imply its endorsement, recommendation, or favoring by the United States Government or any agency thereof. The views and opinions of authors expressed herein do not necessarily state or reflect those of the United States Government or any agency thereof. 
Environmental Sciences Division

Environmental Emissions Nonenergy Benefits Working Paper: ARRA Period

David Carroll, APPRISE, Inc.

Daniel Bausch, APPRISE, Inc.

March 2015

Prepared by

OAK RIDGE NATIONAL LABORATORY

Oak Ridge, TN 37831-6283

managed by

UT-BATTELLE, LLC

for the

US DEPARTMENT OF ENERGY

under contract DE-AC05-00OR22725 



\section{CONTENTS}

CONTENTS

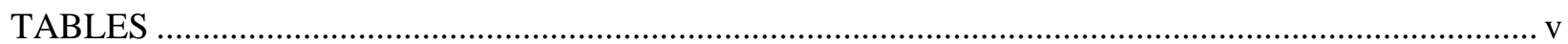

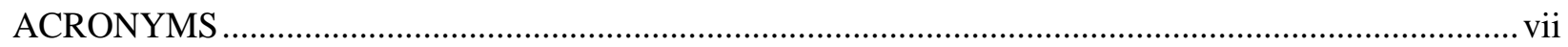

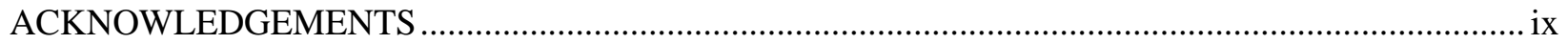

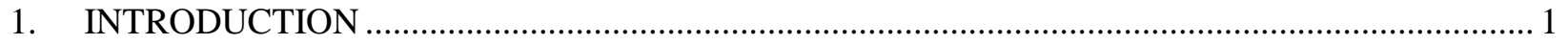

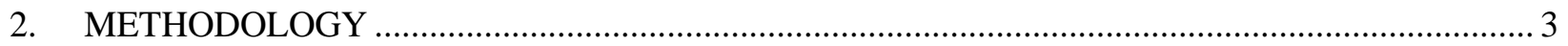

3. BENEFITS FROM GREENHOUSE GAS EMISSIONS REDUCTIONS ................................. 5

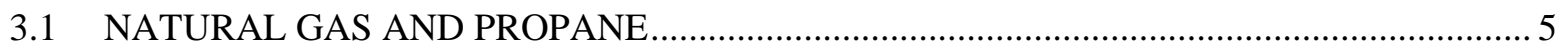

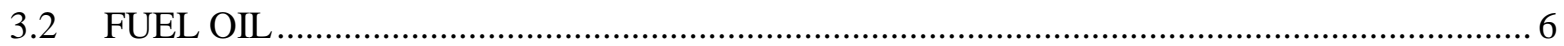

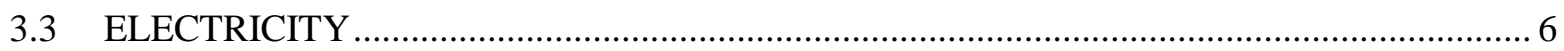

3.4 ESTIMATING THE VALUE OF AVOIDED GREENHOUSE GAS EMISSIONS

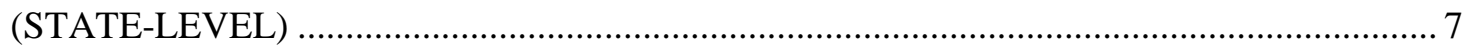

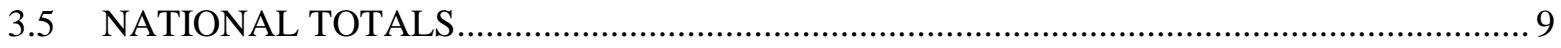

4. BENEFITS FROM SULFUR DIOXIDE EMISSIONS REDUCTIONS …................................ 11

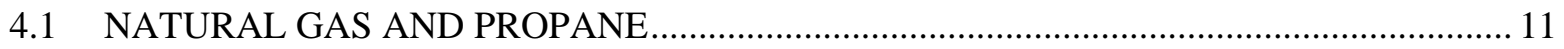

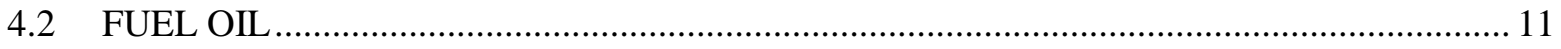

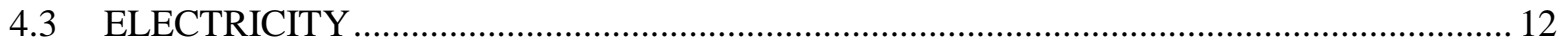

4.4 ESTIMATING THE VALUE OF AVOIDED SULFUR DIOXIDE EMISSIONS

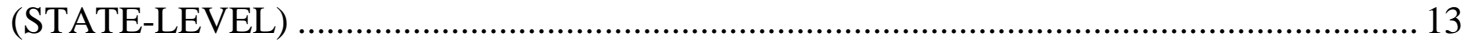

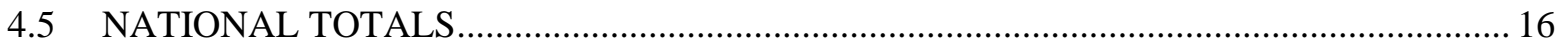

5. BENEFITS FROM NITROGEN OXIDE GAS EMISSIONS REDUCTIONS ….......................... 19

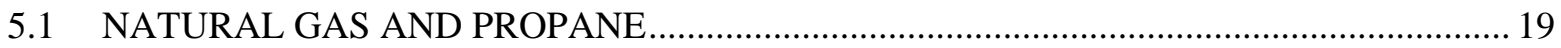

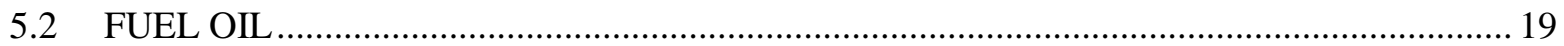

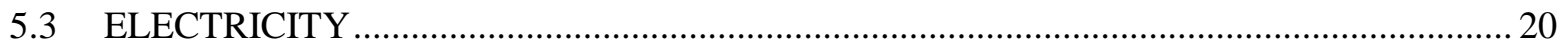

5.4 ESTIMATING THE VALUE OF AVOIDED NITROGEN OXIDE EMISSIONS

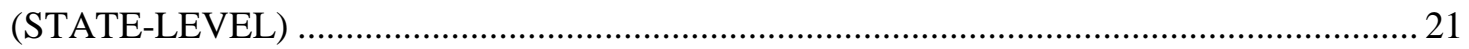

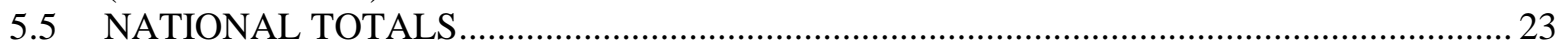

6. BENEFITS FROM PM 2.5 EMISSIONS REDUCTIONS ….................................................... 27

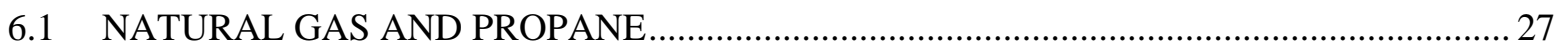

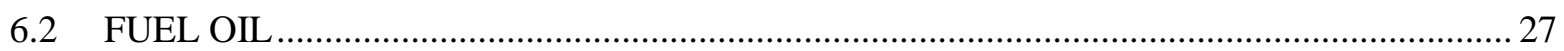

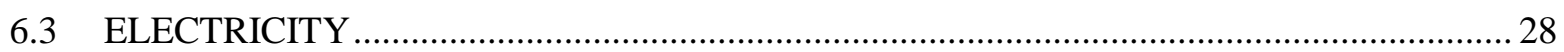

6.4 ESTIMATING THE VALUE OF AVOIDED PARTICULATE MATTER EMISSIONS

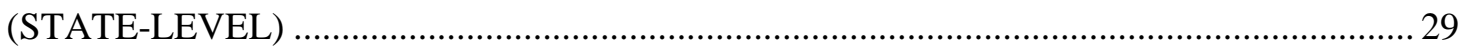

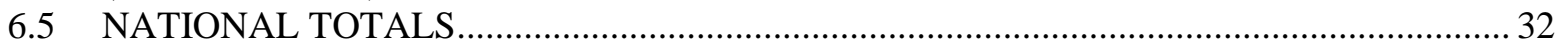

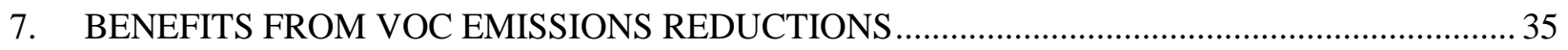

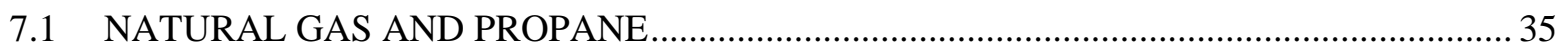

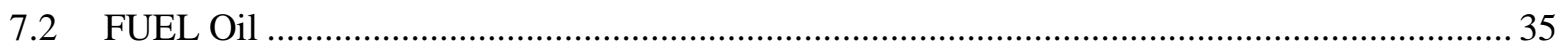

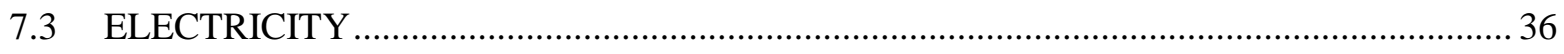

7.4 ESTIMATING THE VALUE OF AVOIDED VOLATILE ORGANIC COMPOUNDS

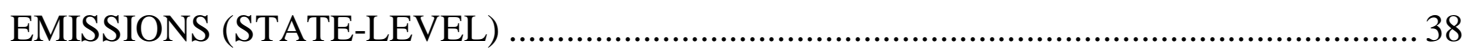

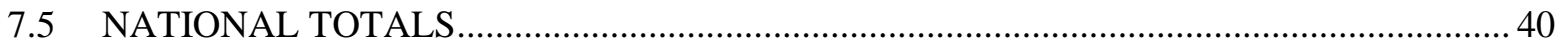

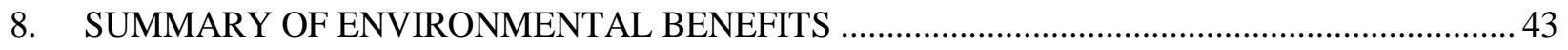





\section{TABLES}

Table

Table 3.1 Avoided Emissions for $\mathrm{CO}_{2}$ EquivalentsNatural Gas and Propane Usage Reductions -

Representative State.

Table 3.2 Avoided Emissions for $\mathrm{CO}_{2}$ Equivalents Fuel Oil Usage Reductions - Representative

State

Table 3.3 Avoided Emissions for $\mathrm{CO}_{2}$ Equivalents Electricity Usage Reductions - Representative

Table 3.4 Social Cost of $\mathrm{CO}_{2}$ Equivalents (\$ per metric ton)By Year (Nominal and 2013 Dollars)

Table 3.5 Quantity and Value of Avoided Emissions for $\mathrm{CO}_{2}$ Equivalents Value per Unit by Fuel

Type and Year (2013 Dollars) - Representative State

6 Quantity and Value of Avoided Emissions for $\mathrm{CO}_{2}$ Equivalents Aggregate Value -

Table 3.6 Quantity and Value
Representative State

Table 3.7 Quantity of Avoided Emissions for $\mathrm{CO}_{2}$ Equivalents National Aggregate Total by Fuel

Type and Year.

Table 3.8 Value of Avoided Emissions for $\mathrm{CO}_{2}$ Equivalents National Aggregate Total by Fuel

Type and Year.

Table 3.9 Quantity and Value of Avoided Emissions for $\mathrm{CO}_{2}$ Equivalents Per Housing Unit -

National.

Table 4.1 Avoided Emissions for $\mathrm{SO}_{2}$ Natural Gas and Propane Usage Reductions -

Representative State.

Table 4.2 Avoided Emissions for $\mathrm{SO}_{2}$ Fuel Oil Usage Reductions - Representative State

Table 4.3 Avoided Emissions for $\mathrm{SO}_{2}$ Electricity Usage Reductions - Representative State.........

Table 4.4 Social Cost of $\mathrm{SO}_{2}$ (\$ per short ton) By Year (Nominal and 2013 Dollars) -

Representative State.

Table 4.5 Quantity and Value of Avoided Emissions for $\mathrm{SO}_{2}$ Value per Unit by Fuel Type and

Year (2013 Dollars) - Representative State.

Table 4.6 Quantity and Value of Avoided Emissions for $\mathrm{SO}_{2}$ Aggregate Value - Representative

State

Table 4.7 Quantity of Avoided Emissions for $\mathrm{SO}_{2}$ National Aggregate Total by Fuel Type and

Year.

Table 4.8 Value of Avoided Emissions for $\mathrm{SO}_{2}$ National Aggregate Total by Fuel Type and Year .......... 16

Table 4.9 Quantity and Value of Avoided Emissions for $\mathrm{SO}_{2}$ Per Housing Unit - National .................... 17

Table 5.1 Avoided Emissions for $\mathrm{NO}_{\mathrm{x}}$ Natural Gas and Propane Usage Reductions -

Representative State.

Table 5.2 Avoided Emissions for $\mathrm{NO}_{\mathrm{x}}$ Fuel Oil Usage Reductions - Representative State ........................ 20

Table 5.3 Avoided Emissions for $\mathrm{NO}_{\mathrm{x}}$ Electricity Usage Reductions - Representative State................... 21

Table 5.4 Social Cost of $\mathrm{NO}_{\mathrm{x}}$ (\$ per short ton) By Year (Nominal and 2013 Dollars) -

Representative State.

Table 5.5 Quantity and Value of Avoided Emissions for $\mathrm{NO}_{\mathrm{x}}$ Value per Unit by Fuel Type and

Year (2013 Dollars) - Representative State.

Table 5.6 Quantity and Value of Avoided Emissions for $\mathrm{NO}_{\mathrm{x}}$ Aggregate Value - Representative

State

Table 5.7 Quantity of Avoided Emissions for $\mathrm{NO}_{\mathrm{x}}$ National Aggregate Total by Fuel Type and

Year.

Table 5.8 Value of Avoided Emissions for $\mathrm{NO}_{\mathrm{x}}$ National Aggregate Total by Fuel Type and Year.......... 24

Table 5.9 Quantity and Value of Avoided Emissions for $\mathrm{NO}_{\mathrm{x}}$ Per Housing Unit - National. 
Table 6.1 Avoided Emissions for PM 2.5 Natural Gas and Propane Usage Reductions -

Representative State

Table 6.2 Avoided Emissions for PM 2.5 Fuel Oil Usage Reductions - Representative State ................. 28

Table 6.3 Avoided Emissions for PM 2.5 Electricity Usage Reductions - Representative State...............29

Table 6.4 Social Cost of PM 2.5 (\$ per short ton) By Year (Nominal and 2013 Dollars) -

Representative State

Table 6.5 Quantity and Value of Avoided Emissions for PM 2.5 Value per Unit by Fuel Type and

Year (2013 Dollars) - Representative State.

Table 6.6 Quantity and Value of Avoided Emissions for PM 2.5 Aggregate Value -

Representative State.

Table 6.7 Quantity of Avoided Emissions for PM 2.5 National Aggregate Total by Fuel Type and

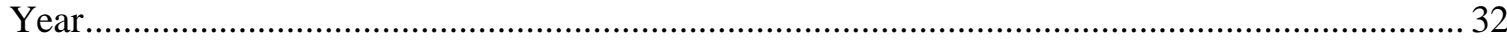

Table 6.8 Value of Avoided Emissions for PM 2.5 National Aggregate Total by Fuel Type and

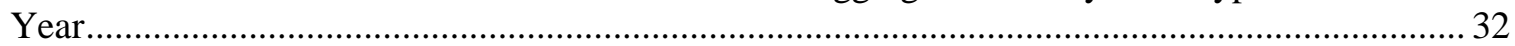

Table 6.9 Quantity and Value of Avoided Emissions for PM 2.5 Per Housing Unit - National ............... 33

Table 7.1 Avoided Emissions for VOC Natural Gas and Propane Usage Reductions -

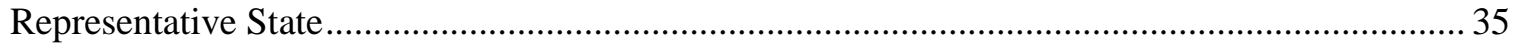

Table 7.2 Avoided Emissions for VOC Fuel Oil Usage Reductions - Representative State..................... 36

Table 7.3 Avoided Emissions for VOC Electricity Usage Reductions - Representative State .................. 38

Table 7.4 Social Cost of VOC (\$ per short ton) By Year (Nominal and 2013 Dollars) -

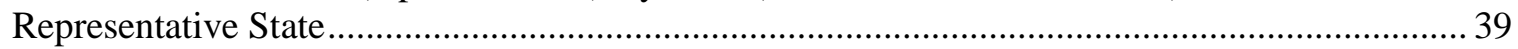

Table 7.5 Quantity and Value of Avoided Emissions for VOC Value per Unit by Fuel Type and Year (2013 Dollars) - Representative State.............................................................................. 40

Table 7.6 Quantity and Value of Avoided Emissions for VOC Aggregate Value - Representative State 40

Table 7.7 Quantity of Avoided Emissions for VOC National Aggregate Total by Fuel Type and Year............................................................................................................................... 41

Table 7.8 Value of Avoided Emissions for VOC National Aggregate Total by Fuel Type and Year ........ 41

Table 7.9 Quantity and Value of Avoided Emissions for VOC Per Housing Unit - National .................. 42

Table 8.1 Quantity and Value of Avoided Emissions by Type of Emissions Aggregate and Per Housing Unit - National.

Table 8.2 Value of Avoided Emissions by Type of Emissions and Fuel Type Aggregate Value National. 


\section{ACRONYMS}

$\begin{array}{ll}\text { APEEP } & \text { Air Pollution Emission Experiments and Policy Analysis Model } \\ \text { ARRA } & \text { American Recovery and Reinvestment Act } \\ \text { BTU } & \text { British Thermal Units } \\ \text { CH4 } & \text { Methane } \\ \text { CO2 } & \text { Carbon Dioxide } \\ \text { DOE } & \text { U.S. Department of Energy } \\ \text { EPA } & \text { Environmental Protection Agency } \\ \text { kWh } & \text { Kilowatt hour } \\ \text { LBS } & \text { Pounds } \\ \text { MCF } & \text { Million Cubic Feet } \\ \text { MMbtu } & \text { Million British Thermal Units } \\ \text { NERC } & \text { North American Electric Reliability Corporation } \\ \text { NO2 } & \text { Nitrogen Dioxide } \\ \text { NOx } & \text { Nitrogen Oxides } \\ \text { NRC } & \text { National Research Council } \\ \text { OMB } & \text { U.S. Office of Management and Budget } \\ \text { OWIP } & \text { Office of Weatherization and Intergovernmental Programs } \\ \text { PM } & \text { Particulate Matter } \\ \text { VOC } & \text { Volatile Organic Compound } \\ \text { WAP } & \text { Weather Assistance Program }\end{array}$





\section{ACKNOWLEDGEMENTS}

The work presented in this report was funded by the U.S. Department of Energy's (DOE) Office of Weatherization and Intergovernmental Programs (OWIP). 



\section{INTRODUCTION}

Weatherization reduces energy usage by low-income households, and thereby reduces the environmental impacts of the production and consumption of energy and reduces the social costs associated with those environmental impacts. The nonenergy benefits study conducted as part of the American Recovery and Reinvestment Act of 2009 (ARRA) Weatherization Assistance Program (WAP) evaluation focused on measuring the emissions reductions resulting from WAP program energy usage reductions and estimating the societal value of those emission reductions. While there are other environmental impacts associated with the WAP program, this study focused on emissions impacts because the 2010 National Research Council (NRC) report Hidden Costs of Energy: The Unpriced Consequences of Energy Production and Use recommended that Congress focus on emissions costs because they have the highest documented social impact costs. 



\section{METHODOLOGY}

The starting point for estimating emissions nonenergy benefits is to measure the program energy impacts. The American Recovery and Reinvestment Act of 2009 (ARRA) Weatherization Assistance Program (WAP) evaluation measured electric and natural gas energy savings using billing data furnished by energy suppliers for a sample of WAP clients and measured fuel oil savings by directly metering homes heated with fuel oil for a sample of clients that were treated by the program. The evaluation then projected energy savings by fuel and housing unit type for each state (i.e., grantee) using state-specific data on WAP production and installed measures.

The analysis used projected energy savings by building type and state to estimate reductions in state-level emissions. There are two reasons for estimating emissions at the state level. First, emissions associated with electric production are best estimated for North American Reliability Corporation (NERC) regions; each state is assigned to a NERC region and emissions per $\mathrm{kWh}$ are estimated for all electric power plants in the region. Second, Air Pollutions Emission Experiments and Policy Analysis Model (APEEP) damage function estimates based on existing emission levels, population, and other local factors; the social cost of a ton of emissions varies substantially from state to state.

The analysis used the APEEP model (recommended by the NRC and updated for purposes of the evaluation) to estimate value of state-level emissions benefits for each of the major criteria air pollutants $\left(\mathrm{SO}_{2}, \mathrm{NO}_{\mathrm{x}}, \mathrm{PM} 2.5\right.$, and VOC). It used $\mathrm{OMB}$ guidance on greenhouse gases $\left(\mathrm{CO}_{2}\right.$ equivalents) to estimate the value of greenhouse gas emission reductions. National estimates were developed by cumulating statelevel values.

This approach to the estimation of emissions benefits is different from what is found in most of the literature on low-income weatherization in two ways. First, most of the literature sources reviewed for this study had lower estimates of the cost per ton for emissions. The estimates in previous studies were generally based on the market price of emissions as established in interstate and/or international emissions trading markets. This study used U.S. Office of Management and Budget (OMB) guidance for valuation of greenhouse gas emissions and the APEEP model for valuation of criteria air pollutant emissions.

Second, most of the literature sources reviewed for this study has substantially higher emissions rates per $\mathrm{kWh}$ for electricity generation that are reported here. In recent years, there have been substantial reductions in emissions at electric generation plants. By using updated emissions data and by adopting the NRC recommendation of projecting continued reductions in emissions over the analysis time period, the study projected much lower levels of avoided emissions associated with electricity usage reductions. The net effect of these two changes is that this study has higher estimated emissions benefits per weatherized unit than many previously published reports despite showing having lower levels avoided emissions. 



\section{BENEFITS FROM GREENHOUSE GAS EMISSIONS REDUCTIONS}

The estimates of avoided greenhouse gas emissions are made separately for natural gas and propane, fuel oil, and electricity. Each type of fuel has a different amount of avoided greenhouse gases per unit of energy savings. In addition, for electricity, the amount of avoided greenhouse gases varies by geography because of differences in the fuels used to generate electricity in each geographic area.

The unit used for quantification of greenhouse gases is $\mathrm{CO}_{2}$ equivalents. Greenhouse gases include $\mathrm{CO}_{2}$, $\mathrm{CH}_{4}$, and $\mathrm{N}_{2} \mathrm{O}$. Any emissions of $\mathrm{CH}_{4}$ or $\mathrm{N}_{2} \mathrm{O}$ are transformed into their $\mathrm{CO}_{2}$ equivalent using the global warming potential furnished by EPA. ${ }^{1}$

\subsection{NATURAL GAS AND PROPANE}

The 2010 NRC report ${ }^{2}$ furnished recommendations for computing the greenhouse gases associated with the extraction and combustion of natural gas. The report recommended using a value of $140 \mathrm{lbs}$ per MCF of natural gas used (.062 metric tons per MMBtu). That includes $20 \mathrm{lbs}$ per MCF for extraction and 120 pounds per MCF for combustion. The sources cited by the NRC report include Jaramillo $(2007)^{3}$ for upstream (i.e., extraction) and EPA AP- $42^{4}$ for downstream (i.e., combustion).

Table 3.1 shows how avoided emissions were computed for one state studied in the WAP evaluation. The calculation for the representative state shows that the average projected savings per unit in the first program year would be 118.56 therms and the avoided emissions per unit would be 0.73 metric tons. The projected lifetime savings per unit would be 2,535.80 therms and the lifetime avoided emissions would be 15.71 metric tons. (Note that installed measures vary in terms of their estimated lifetime. For measures that affect natural gas and propane usage, the lifetime varies between 13 years for a setback thermostat to 25 years for insulation. So, the average savings per unit are lower in some of the later years.)

Table 3.1 Avoided Emissions for $\mathrm{CO}_{2}$ Equivalents Natural Gas and Propane Usage Reductions Representative State

\begin{tabular}{|l|c|c|c|c|}
\hline Year & $\begin{array}{c}\text { Savings per } \\
\text { Housing Unit } \\
\text { (therms) }^{\mathbf{5}}\end{array}$ & $\begin{array}{c}\text { Savings per } \\
\text { Housing Unit } \\
\text { (MMBtu) }\end{array}$ & $\begin{array}{c}\text { Rate (Metric } \\
\text { Tons/MMBtu) }\end{array}$ & $\begin{array}{c}\text { Metric Tons per } \\
\text { Housing Unit }\end{array}$ \\
\hline First Year & 118.56 & 11.86 & 0.0620 & 0.73 \\
\hline Lifetime & $2,535.80$ & 253.58 & 0.0620 & 15.71 \\
\hline
\end{tabular}

For this calculation, it was assumed that the greenhouse gas emission rates for propane were the same as the rates for natural gas. While that is likely to be a reliable assumption for combustion, it is possible that

\footnotetext{
${ }^{1}$ U.S. Environmental Protection Agency Overview of Greenhouse Gases Methane Emission/ Environmental Protection Agency, September 9, 2013, Web. Accessed January 7, 2014. The CO2 equivalents (methane $=21$, nitrous oxide $=310$ ) are on the web pages: http://www.epa.gov/climatechange/ghgemissions/gases/ch4.html and http://www.epa.gov/climatechange/ghgemissions/gases/n2o.html.

${ }^{2}$ National Research Council 2010 Hidden Costs of Energy: Unpriced Consequences of Energy Production and Use. National Academy Press, page 12 .

${ }^{3}$ Jaramillo, P., W.M. Griffin, and H.S. Matthews. 2007. Comparative life cycle air emissions of coal, domestic natural gas, LNG, and SNG for electricity generation. Environ. Sci. Technol. 41(17):6290-6296.

${ }^{4}$ January 1995 U.S. Environmental Protection Agency Compilation of Air Pollutant Emission Factors. Vol. 1. Stationary Point and Area Sources, 5th Ed. AP-42. Environmental Protection Agency. Pp 1.1-5 Web. Accessed April 23, 2009.

${ }^{5}$ The savings per housing unit for any state is the projected aggregate natural gas and propane savings from housing units that use one of those fuels divided by the total number of housing units served by the program in that state.
} 
the process for producing propane has different upstream emissions. However, since propane is a small part of the total energy savings associated with the program (12.4\% of savings in the example state), the potential bias is small.

\subsection{FUEL OIL}

The fuel oil $\mathrm{CO}_{2}$ equivalent emissions rate was computed using several sources.

1. EIA provides $\mathrm{CO}_{2}$ emissions factors for a range of fuels in the Technical Guidelines for Voluntary Reporting of Greenhouse Gases. ${ }^{6}$ The emission factor for fuel oil used in homes and multifamily buildings was listed as $72.32 \mathrm{~kg}$ of $\mathrm{CO}_{2}$ per MMBtu.

2. EPA furnishes estimates of the $\mathrm{CH}_{4}$ and $\mathrm{N}_{2} \mathrm{O}$ emissions factors in AP-42, Compilation of Air Pollutant Emissions. ${ }^{7}$ For residential furnaces, emissions were estimated to be $1.78 \mathrm{lbs}$ of $\mathrm{CH}_{4}$ and $0.05 \mathrm{lbs}$ of $\mathrm{N}_{2} \mathrm{O}$ per $10^{3}$ gallons of fuel oil.

The total $\mathrm{CO}_{2}$ equivalent for fuel oil is estimated to be 0.0727 metric tons per MMBtu.

Table 3.2 shows how avoided emissions were computed for one state studied in the WAP evaluation. The calculation for the representative state shows that the average projected savings per unit in the first program year would be 6.84 gallons and the avoided emissions per unit would be 0.07 metric tons. The projected lifetime savings per unit would be 149.99 gallons and the lifetime avoided emissions would be 1.51 metric tons. (Note that the installed measures vary in terms of their estimated lifetime. For measures that affect fuel oil, the lifetime varies between 13 years for a setback thermostat to 25 years for insulation. So, the average savings per unit are lower in some of the later years.)

Table 3.2 Avoided Emissions for $\mathrm{CO}_{2}$ Equivalents Fuel Oil Usage Reductions - Representative State

\begin{tabular}{|l|c|c|c|c|}
\hline \multicolumn{1}{|c|}{ Year } & $\begin{array}{c}\text { Savings per } \\
\text { Housing Unit } \\
\text { (Gallons) }^{\mathbf{8}}\end{array}$ & $\begin{array}{c}\text { Savings per } \\
\text { Housing Unit } \\
\text { (MMBtu) }\end{array}$ & $\begin{array}{c}\text { Rate (Metric } \\
\text { Tons/MMBtu) }\end{array}$ & $\begin{array}{c}\text { Metric Tons per } \\
\text { Housing Unit }\end{array}$ \\
\hline First Year & 6.84 & 0.95 & 0.0727 & 0.07 \\
\hline Lifetime & 149.99 & 20.80 & 0.0727 & 1.51 \\
\hline
\end{tabular}

\subsection{ELECTRICITY}

The estimate of the emission rates for electricity is based on reported data for the NERC region in which the state is located. EPA's NERC emission summary tables were released in 2012. ${ }^{9}$ These tables furnish estimates of baseload and non-baseload emission rates for each NERC region. For this analysis, we used

\footnotetext{
${ }^{6}$ U.S. Department of Energy, Technical Guidelines Voluntary Reporting of Greenhouse Gases (1605(b)) Program, Chapter 1, Part C, Stationary Source Combustion, January 2007. Page 43.

${ }^{7}$ AP42, Compilation of Air Pollution Emission Factors, Volume 1: Stationary Point and Area Sources, Chapter 1: External Combustion Sources. http://www.epa.gov/ttnchie1/ap42/ch01/ Section 1.3 Fuel Oil Combustion Final Section - Supplement E September 1999, corrected May 2010. CH4 factor is on page 14 and N2O factor is on page 20. http://www.epa.gov/ttn/chief/ap42/ch01/final/c01s03.pdf.

${ }^{8}$ The savings per housing unit for any state is the projected aggregate fuel oil savings from housing units that use fuel oil divided by the total number of housing units served by the program in that state.

${ }^{9}$ EPA eGRID2012 Version 1.0 Year 2009 Summary Tables. Environmental Protection Agency. Washington D.C. April, 2012.
} 
the non-baseload emission rates for the NERC region in which the majority of each state's population resides, as recommended by the EPA. ${ }^{10}$

These tables furnish emission rates for $\mathrm{CO}_{2}$ equivalents per $\mathrm{kWh}$ generated at the source. We adjusted the $\mathrm{kWh}$ savings from the WAP evaluation to account for transmission losses. These estimates are provided in the EPA NERC summary tables. ${ }^{11}$

Table 3.3 shows how avoided emissions were computed for one state studied in the WAP evaluation. The calculation for the representative state shows that the average projected savings per unit in the first program year would be $678 \mathrm{kWh}$ and the avoided emissions per unit would be 0.68 metric tons. The projected lifetime savings would be $7,874 \mathrm{kWh}$ and the lifetime avoided emissions would be 7.87 metric tons. (Note that the installed measures vary in terms of their estimated lifetime. For measures that affect electricity, the lifetime varies between 7 years for lighting to 25 years for insulation. So, the average savings per unit are lower in some of the later years.)

Table 3.3 Avoided Emissions for $\mathrm{CO}_{2}$ Equivalents Electricity Usage Reductions - Representative State

\begin{tabular}{|l|c|c|c|c|c|}
\hline Year & $\begin{array}{c}\text { Savings per } \\
\text { Housing Unit } \\
\text { (kWh Site) }\end{array}$ & $\begin{array}{c}\text { Savings per } \\
\text { Housing } \\
\text { Unit (kWh } \\
\text { Source }\end{array}$ & $\begin{array}{c}\text { Savings per } \\
\text { Housing Unit } \\
\text { (MMBtu } \\
\text { Source) }\end{array}$ & $\begin{array}{c}\text { Rate (Metric } \\
\text { Tons/MMBtu) }\end{array}$ & $\begin{array}{c}\text { Metric Tons } \\
\text { per Housing } \\
\text { Unit }\end{array}$ \\
\hline First Year & 678 & 720 & 2.46 & 0.2758 & 0.68 \\
\hline Lifetime & 7,874 & 8,361 & 28.53 & 0.2758 & 7.87 \\
\hline
\end{tabular}

For some emissions, the NRC observed that emission rates are expected to decline over time. The report recommended explicitly accounting for those expected reductions in emissions. They made no such recommendation for the emissions of greenhouse gases.

\subsection{ESTIMATING THE VALUE OF AVOIDED GREENHOUSE GAS EMISSIONS (STATE- LEVEL)}

The Office of Management and Budget issued a technical document in May 2013 that furnishes guidance for estimating the social cost of carbon. ${ }^{12}$ That document furnishes the current social cost of carbon and annual values for the future cost through 2050. Table 3.4 shows cost statistics for the target analysis period - 2013 through 2037 - in nominal dollars and 2013 dollars (i.e., discounted by the recommended real discount rate furnished by $\mathrm{OMB}) .^{13}$

\footnotetext{
${ }^{10}$ Art Diem and Cristina Quiroz, How to use eGRID for Carbon Footprinting Electricity Purchases in Greenhouse Gas Emission Inventories. Environmental Protection Agency. Washington D.C. Page 10-11. July 2012.

${ }^{11}$ EPA eGRID2012 Version 1.0 Year 2009 Summary Tables. Environmental Protection Agency. Washington D.C. April, 2012. Pages $7 \& 9$.

${ }^{12}$ OMB Technical Support Document: Technical Update of the Social Cost of Carbon for Regulatory Impact Analysis Under Executive Order 12866 Interagency Working Group on Social Cost of Carbon, United States Government. May 2013. Page 18.

${ }^{13}$ Jeffrey D. Zients M-13-04 Memorandum for the Heads of Departments and Agencies. Executive Office of Management and Budget. January 24, 2013.
} 
Table 3.4 Social Cost of $\mathrm{CO}_{2}$ Equivalents (\$ per metric ton) By Year (Nominal and 2013 Dollars) Representative State

\begin{tabular}{|l|c|c|}
\hline Year & $\begin{array}{c}\text { \$ Per Metric Ton } \\
\text { (Nominal Value) }\end{array}$ & $\begin{array}{c}\text { \$ Per Metric Ton } \\
\text { (2013 Dollars) }\end{array}$ \\
\hline 2013 & $\$ 40.32$ & $\$ 40.32$ \\
\hline 2014 & $\$ 41.44$ & $\$ 40.23$ \\
\hline 2015 & $\$ 42.56$ & $\$ 40.12$ \\
\hline 2016 & $\$ 43.68$ & $\$ 39.97$ \\
\hline 2017 & $\$ 44.80$ & $\$ 39.80$ \\
\hline Average for first five years & $\$ 42.56$ & $\$ 40.09$ \\
\hline Average for analysis period & $\$ 50.48$ & $\$ 38.03$ \\
\hline
\end{tabular}

For a representative state, the avoided emissions per housing unit are listed in Tables 3.1-3.3. The total avoided emissions per housing unit for all energy types is multiplied by the dollars per metric ton in 2013 dollars to estimate the avoided emission benefit per unit at the state level. Table 3.5 shows that calculation for a representative state. The aggregate emissions benefit for the state is estimated using the average per unit times the number of units served. Table 3.6 shows the calculation for a representative state.

Table 3.5 Quantity and Value of Avoided Emissions for $\mathrm{CO}_{2}$ Equivalents Value per Unit by Fuel Type and Year (2013 Dollars) - Representative State

\begin{tabular}{|l|c|c|c|c|c|c|c|c|}
\hline \multirow{2}{*}{} & \multicolumn{2}{|c|}{$\begin{array}{c}\text { Natural } \\
\text { Gas/Propane }\end{array}$} & \multicolumn{2}{|c|}{ Fuel Oil } & \multicolumn{2}{|c|}{ Electricity } & \multicolumn{2}{c|}{ All Fuels } \\
\cline { 2 - 10 } Year & $\begin{array}{c}\text { Metric } \\
\text { Tons } \\
\text { per Unit }\end{array}$ & $\begin{array}{c}\text { \$ per } \\
\text { Unit }\end{array}$ & $\begin{array}{c}\text { Metric } \\
\text { Tons } \\
\text { per Unit }\end{array}$ & $\begin{array}{c}\text { \$ per } \\
\text { Unit }\end{array}$ & $\begin{array}{c}\text { Metric } \\
\text { Tons } \\
\text { per Unit }\end{array}$ & $\begin{array}{c}\text { \$ per } \\
\text { Unit }\end{array}$ & $\begin{array}{c}\text { Metric } \\
\text { Tons } \\
\text { per Unit }\end{array}$ & $\begin{array}{c}\text { \$ per } \\
\text { Unit }\end{array}$ \\
\hline 2013 & 0.73 & $\$ 29.62$ & 0.07 & $\$ 2.78$ & 0.68 & $\$ 27.32$ & 1.48 & $\$ 59.72$ \\
\hline 2014 & 0.73 & $\$ 29.55$ & 0.07 & $\$ 2.78$ & 0.68 & $\$ 27.26$ & 1.48 & $\$ 59.59$ \\
\hline 2015 & 0.73 & $\$ 29.47$ & 0.07 & $\$ 2.77$ & 0.68 & $\$ 27.19$ & 1.48 & $\$ 59.42$ \\
\hline 2016 & 0.73 & $\$ 29.36$ & 0.07 & $\$ 2.76$ & 0.68 & $\$ 27.09$ & 1.48 & $\$ 59.21$ \\
\hline 2017 & 0.73 & $\$ 29.24$ & 0.07 & $\$ 2.75$ & 0.68 & $\$ 26.97$ & 1.48 & $\$ 58.96$ \\
\hline First five years & 3.67 & $\$ 147.23$ & 0.34 & $\$ 13.83$ & 3.39 & $\$ 135.83$ & 7.41 & $\$ 296.89$ \\
\hline Lifetime & 15.71 & $\$ 591.57$ & 1.51 & $\$ 56.82$ & 7.87 & $\$ 308.29$ & 25.09 & $\$ 956.69$ \\
\hline
\end{tabular}


Table 3.6 Quantity and Value of Avoided Emissions for $\mathrm{CO}_{2}$ Equivalents Aggregate Value - Representative State

\begin{tabular}{|c|c|c|c|c|c|}
\hline Year & Units & $\begin{array}{l}\text { Metric Tons } \\
\text { Per Unit (All } \\
\text { Fuels) }\end{array}$ & $\begin{array}{c}\text { Aggregate } \\
\text { Metric Tons }\end{array}$ & $\begin{array}{c}\text { Value per } \\
\text { Unit }(2013 \\
\text { Dollars - All } \\
\text { Fuels) }\end{array}$ & $\begin{array}{c}\text { Aggregate } \\
\text { Value (2013 } \\
\text { Dollars - All } \\
\text { Fuels) }\end{array}$ \\
\hline 2013 & 14,417 & 1.48 & 21,353 & $\$ 59.72$ & $\$ 860,971$ \\
\hline 2014 & 14,417 & 1.48 & 21,353 & $\$ 59.59$ & $\$ 859,114$ \\
\hline 2015 & 14,417 & 1.48 & 21,353 & $\$ 59.42$ & $\$ 856,634$ \\
\hline 2016 & 14,417 & 1.48 & 21,353 & $\$ 59.21$ & $\$ 853,570$ \\
\hline 2017 & 14,417 & 1.48 & 21,353 & $\$ 58.96$ & $\$ 849,958$ \\
\hline First five years & 14,417 & 7.41 & 106,767 & $\$ 296.89$ & $\$ 4,280,247$ \\
\hline Lifetime & 14,417 & 25.09 & 361,740 & $\$ 956.69$ & $\$ 13,792,542$ \\
\hline
\end{tabular}

\subsection{NATIONAL TOTALS}

The state-level analysis furnishes information on the aggregate avoided emissions, the aggregate emissions benefit, and the number of units served for each state. Those are cumulated to develop the aggregate national value of avoided emissions. Table 3.7 shows the aggregate quantity of avoided emissions by fuel type. Table 3.8 shows the aggregate value of avoided emissions by fuel type. In total, the analysis shows that if the 2010 WAP program were implemented in 2013 , it would be expected to result in a total reduction of 7,382,524 metric tons of $\mathrm{CO}_{2}$ emissions (Table 3.7) at a lifetime value of $\$ 281,573,912$ (Table 3.8). About 46 percent of the avoided emissions are from the reduction in the use of natural gas and propane, 10 percent from reduction in the use of fuel oil, and 44 percent from reduction in the use of electricity.

Table 3.7 Quantity of Avoided Emissions for $\mathrm{CO}_{2}$ Equivalents National Aggregate Total by Fuel Type and Year

\begin{tabular}{|l|c|c|c|c|}
\hline \multirow{2}{*}{ Year } & \multicolumn{3}{|c|}{ Avoided Emissions (Metric Tons of CO } \\
\cline { 2 - 5 } & $\begin{array}{c}\text { Natural } \\
\text { Gas/Propane }\end{array}$ & Fuel Oil & Electricity & \multirow{2}{*}{ All Fuels } \\
\hline First Year & 161,916 & 36,104 & 228,784 & 426,804 \\
\hline Lifetime & $3,384,103$ & 753,205 & $3,245,217$ & $7,382,524$ \\
\hline
\end{tabular}


Table 3.8 Value of Avoided Emissions for $\mathrm{CO}_{2}$ Equivalents National Aggregate Total by Fuel Type and Year

\begin{tabular}{|l|c|c|c|c|}
\hline \multirow{2}{*}{ Year } & \multicolumn{3}{|c|}{ Avoided Emissions (2013 Dollars) } \\
\cline { 2 - 5 } & $\begin{array}{c}\text { Natural } \\
\text { Gas/Propane }\end{array}$ & Fuel Oil & Electricity & All Fuels \\
\hline 2013 & $\$ 6,528,454$ & $\$ 1,455,708$ & $\$ 9,224,555$ & $\$ 17,208,717$ \\
\hline 2014 & $\$ 6,514,368$ & $\$ 1,452,567$ & $\$ 9,204,653$ & $\$ 17,171,589$ \\
\hline 2015 & $\$ 6,495,566$ & $\$ 1,448,375$ & $\$ 9,178,085$ & $\$ 17,122,026$ \\
\hline 2016 & $\$ 6,472,332$ & $\$ 1,443,194$ & $\$ 9,145,256$ & $\$ 17,060,782$ \\
\hline 2017 & $\$ 6,444,940$ & $\$ 1,437,086$ & $\$ 9,106,553$ & $\$ 16,988,580$ \\
\hline First five years & $\$ 32,455,659$ & $\$ 7,236,931$ & $\$ 45,859,103$ & $\$ 85,551,692$ \\
\hline Lifetime & $\$ 127,664,103$ & $\$ 28,409,661$ & $\$ 125,500,144$ & $\$ 281,573,912$ \\
\hline
\end{tabular}

Table 3.9 shows the calculation for the average amount of avoided emissions and the average value per housing unit served by the WAP program. The estimated avoided emissions per housing unit at the national level are 22.25 metric tons with lifetime value of $\$ 848$.

Table 3.9 Quantity and Value of Avoided Emissions for $\mathrm{CO}_{2}$ Equivalents Per Housing Unit - National

\begin{tabular}{|c|c|c|c|c|c|}
\hline Year & Units & $\begin{array}{c}\text { Aggregate } \\
\text { Metric Tons }\end{array}$ & $\begin{array}{c}\text { Metric Tons } \\
\text { Per Unit (All } \\
\text { Fuels) }\end{array}$ & $\begin{array}{c}\text { Aggregate } \\
\text { Value (2013 } \\
\text { Dollars - All } \\
\text { Fuels) }\end{array}$ & $\begin{array}{c}\text { Value Per } \\
\text { Housing Unit } \\
\text { (2013 Dollars } \\
\text { - All Fuels) }\end{array}$ \\
\hline 2013 & 331,866 & 426,804 & 1.29 & $\$ 17,208,717$ & $\$ 51.85$ \\
\hline 2014 & 331,866 & 426,804 & 1.29 & $\$ 17,171,589$ & $\$ 51.74$ \\
\hline 2015 & 331,866 & 426,804 & 1.29 & $\$ 17,122,026$ & $\$ 51.59$ \\
\hline 2016 & 331,866 & 426,804 & 1.29 & $\$ 17,060,782$ & $\$ 51.41$ \\
\hline 2017 & 331,866 & 426,804 & 1.29 & $\$ 16,988,580$ & $\$ 51.19$ \\
\hline First five years & 331,866 & $2,134,017$ & 6.43 & $\$ 85,551,692$ & $\$ 257.79$ \\
\hline Lifetime & 331,866 & $7,382,524$ & 22.25 & $\$ 281,573,912$ & $\$ 848.46$ \\
\hline
\end{tabular}




\section{BENEFITS FROM SULFUR DIOXIDE EMISSIONS REDUCTIONS}

The estimates of avoided $\mathrm{SO}_{2}$ are made separately for natural gas and propane, fuel oil, and electricity. Each type of fuel has a different amount of avoided $\mathrm{SO}_{2}$ per unit of energy savings. In addition, for electricity, the amount of avoided $\mathrm{SO}_{2}$ varies by geographic region because of differences in the $\mathrm{SO}_{2}$ emissions rates for generation plants.

\subsection{NATURAL GAS AND PROPANE}

The EPA furnished an estimate of the $\mathrm{SO}_{2}$ emissions factor from natural gas combustion in boilers and furnaces in AP-42. ${ }^{14}$ Emissions are estimated to be 0.6 pounds of $\mathrm{SO}_{2}$ per $10^{6}$ standard cubic feet of natural gas $\left(2.93 \times 10^{-7}\right.$ short tons per MMBtu).

Table 4.1 shows how avoided emissions were computed for one state studied in the WAP evaluation. The calculation for the representative state shows that the average projected savings per unit in the first program year would be 118.56 therms and the avoided emissions per unit would be $3.47 \times 10^{-6}$ short tons. The projected lifetime savings would be 2,535.80 therms and the lifetime avoided emissions would be $7.42 \times 10^{-5}$ short tons.

Note that the installed measures vary in terms of their estimated lifetime. For measures that affect natural gas and propane usage, the lifetime varies between 13 years for a setback thermostat to 25 years for insulation. So, the average therms of savings per unit are lower in some of the later years.

Table 4.1 Avoided Emissions for $\mathrm{SO}_{2}$ Natural Gas and Propane Usage Reductions - Representative State

\begin{tabular}{|l|c|c|c|c|}
\hline Year & $\begin{array}{c}\text { Savings per } \\
\text { Housing Unit } \\
\text { (therms) }\end{array}$ & $\begin{array}{c}\text { Savings per } \\
\text { Housing Unit } \\
\text { (MMBtu) }\end{array}$ & $\begin{array}{c}\text { Rate (Short } \\
\text { Tons/MMBtu) }\end{array}$ & $\begin{array}{c}\text { Short Tons per } \\
\text { Housing Unit }\end{array}$ \\
\hline First Year & 118.56 & 11.86 & $2.93 \mathrm{E}-07$ & $3.47 \mathrm{E}-06$ \\
\hline Lifetime & $2,535.80$ & 253.58 & $2.93 \mathrm{E}-07$ & $7.42 \mathrm{E}-05$ \\
\hline
\end{tabular}

For this calculation, it was assumed that the greenhouse gas emission rates for propane were the same as the rates for natural gas. While that is likely to be a reliable assumption for combustion, it is possible that the process for producing propane has different upstream emissions. However, since propane is a small part of the total energy savings associated with the program (12.4\% of savings in the example state), the potential bias is small.

\subsection{FUEL OIL}

The fuel oil $\mathrm{SO}_{2}$ emissions rate was computed using the EPA estimated $\mathrm{SO}_{2}$ emissions factor from AP$42^{16}$, Compilation of Air Pollutant Emissions. ${ }^{17}$ The EPA factor is 142 pounds per $10^{3}$ gallons multiplied

\footnotetext{
${ }^{14}$ AP 42, Fifth Edition, Compilation of Air Pollutant Emission Factors, Volume 1: Stationary Point and Area Sources, Chapter 1: External Combustion Sources. http://www.epa.gov/ttnchie1/ap42/ch01/ 1.4 Natural Gas Combustion

Final Section - Supplement D, July 1998. http://www.epa.gov/ttn/chief/ap42/ch01/final/c01s04.pdf page 1.4-6.

${ }^{15}$ The savings per housing unit for any state is the projected aggregate natural gas and propane savings from housing units that use one of those fuels divided by the total number of housing units served by the program in that state.

${ }^{16}$ AP42, Compilation of Air Pollution Emission Factors, Volume 1: Stationary Point and Area Sources, Chapter 1: External Combustion Sources. http://www.epa.gov/ttnchie1/ap42/ch01/ Section 1.3 Fuel Oil Combustion Final Section - Supplement E September 1999, corrected May 2010. http://www.epa.gov/ttn/chief/ap42/ch01/final/c01s03.pdf, page 1.3-12.
} 
by the weight percentage of sulfur in the oil. Our model assumes $50 \%$ sulfur content for residential fuel oil ${ }^{18}$ so the total $\mathrm{SO}_{2}$ emissions for fuel oil are estimated at 71 pounds per $10^{3}$ gallons $\left(2.56 \times 10^{-4}\right.$ short tons per MMBtu).

Table 4.2 shows how avoided emissions were computed for one state studied in the WAP evaluation. The calculation for the representative state shows that the average projected savings per unit in the first program year would be 6.84 gallons and the avoided emissions per unit would be $2.43 \times 10^{-4}$ short tons. The projected lifetime savings would be 149.99 gallons and the lifetime avoided emissions would be 5.32 $\mathrm{x} 10^{-3}$ short tons.

Note that the installed measures vary in terms of their estimated lifetime. For measures that affect fuel oil, the lifetime varies between 13 years for a setback thermostat to 25 years for insulation. So, the average savings per unit are lower in some of the later years.

Table 4.2 Avoided Emissions for $\mathrm{SO}_{2}$ Fuel Oil Usage Reductions - Representative State

\begin{tabular}{|l|c|c|c|c|}
\hline Year & $\begin{array}{c}\text { Savings per } \\
\text { Housing Unit } \\
\text { (Gallons) }^{\mathbf{1 9}}\end{array}$ & $\begin{array}{c}\text { Savings per } \\
\text { Housing Unit } \\
\text { (MMBtu) }\end{array}$ & $\begin{array}{c}\text { Rate (Short } \\
\text { Tons/MMBtu) }\end{array}$ & $\begin{array}{c}\text { Short Tons per } \\
\text { Housing Unit }\end{array}$ \\
\hline First Year & 6.84 & 0.95 & $2.56 \mathrm{E}-04$ & $2.43 \mathrm{E}-04$ \\
\hline Lifetime & 149.99 & 20.80 & $2.56 \mathrm{E}-04$ & $5.32 \mathrm{E}-03$ \\
\hline
\end{tabular}

\subsection{ELECTRICITY}

The estimate of the emissions rates for sulfur dioxide for electricity is based on reported data for the eGRID region in which the state is located. EPA's eGRID emission summary tables were released in 2012. ${ }^{20}$ These tables furnish estimates of baseload and non-baseload emission rates for each NERC region. For this analysis, we used the non-baseload emission rates as recommended by EPA. ${ }^{21}$

These tables furnish emission rates for $\mathrm{SO}_{2}$ per $\mathrm{kWh}$ generated at the source. We adjusted the $\mathrm{kWh}$ savings from the WAP evaluation to account for transmission losses. These estimates are provided in the EPA eGRID summary tables. ${ }^{22}$

Table 4.3 shows how avoided emissions were computed for one state studied in the WAP evaluation. The calculation for the representative state shows that the average projected savings per unit in the first program year would be $678 \mathrm{kWh}$ and the avoided emissions per unit would be $2.07 \times 10^{-3}$ short tons. The projected lifetime savings would be $7,874 \mathrm{kWh}$ and the lifetime avoided emissions would be $2.04 \times 10^{-2}$ short tons.

\footnotetext{
${ }^{17}$ 29. N. F. Suprenant, et al., Emissions Assessment Of Conventional Stationary Combustion Systems, Volume I: Gas And Oil Fired Residential Heating Sources, EPA-600/7-79-029b, U. S. Environmental Protection Agency, Washington, DC, May 1979. ${ }^{18}$ Nishioka et al. "Integrating Risk Assessment and Life Cycle Assessment: A Case Study of Insulation." Risk Analysis. Vol. 22 , no. 5, 2002, p. 1006.

${ }^{19}$ The savings per housing unit for any state is the projected aggregate fuel oil savings from housing units with fuel oil main heat divided by the total number of housing units served by the program in that state.

${ }^{20}$ EPA eGRID2012 Version 1.0 Year 2009 Summary Tables. Environmental Protection Agency. Washington D.C. April, 2012.

${ }^{21}$ Art Diem and Cristina Quiroz, How to use eGRID for Carbon Footprinting Electricity Purchases in Greenhouse Gas Emission Inventories. Environmental Protection Agency. Washington D.C. Page 10-11. July 2012.

${ }^{22}$ EPA eGRID2012 Version 1.0 Year 2009 Summary Tables. Environmental Protection Agency. Washington D.C. April, 2012. Pages $7 \& 9$.
} 
Note that the installed measures vary in terms of their estimated lifetime. For measures that affect electricity, the lifetime varies between 7 years for lighting and 25 years for insulation. So, the average savings per unit are lower in some of the later years.

The NRC observed that emission rates of $\mathrm{SO}_{2}$ from power plants are expected to decline over time due to increased regulation and costs. The report recommended explicitly accounting for those expected reductions in emissions and provided estimates of 2030 emissions reductions varying by pollutant and power plant fuel. ${ }^{23} \mathrm{We}$ chose to apply a rough estimate of a $50 \%$ emissions reduction over the analysis period of 2013 to 2037. This translates to an annual reduction of $2.85 \%$ to the rate of $\mathrm{SO}_{2}$ emissions from electricity generation in our models.

Table 4.3 Avoided Emissions for $\mathrm{SO}_{2}$ Electricity Usage Reductions - Representative State

\begin{tabular}{|l|c|c|c|c|c|}
\hline Year & $\begin{array}{c}\text { Savings per } \\
\text { Housing Unit } \\
\text { (kWh Site) }\end{array}$ & $\begin{array}{c}\text { Savings per } \\
\text { Housing Unit } \\
\text { (kWh Source) }\end{array}$ & $\begin{array}{c}\text { Savings per } \\
\text { Housing Unit } \\
\text { (MMBtu } \\
\text { Source) }\end{array}$ & $\begin{array}{c}\text { Rate (Short } \\
\text { Tons/MMBtu) }\end{array}$ & $\begin{array}{c}\text { Short Tons per } \\
\text { Housing Unit }\end{array}$ \\
\hline 2013 & 678 & 720 & 2.46 & $8.42 \mathrm{E}-04$ & $2.07 \mathrm{E}-03$ \\
\hline 2014 & 678 & 720 & 2.46 & $8.18 \mathrm{E}-04$ & $2.01 \mathrm{E}-03$ \\
\hline 2015 & 678 & 720 & 2.46 & $7.95 \mathrm{E}-04$ & $1.95 \mathrm{E}-03$ \\
\hline 2016 & 678 & 720 & 2.46 & $7.72 \mathrm{E}-04$ & $1.90 \mathrm{E}-03$ \\
\hline 2017 & 678 & 720 & 2.46 & $7.50 \mathrm{E}-04$ & $1.84 \mathrm{E}-03$ \\
\hline First five years & 3,391 & 3,600 & 12.28 & $7.95 \mathrm{E}-04$ & $9.77 \mathrm{E}-03$ \\
\hline Lifetime & 7,874 & 8,361 & 28.53 & $7.15 \mathrm{E}-04$ & $2.04 \mathrm{E}-02$ \\
\hline
\end{tabular}

\subsection{ESTIMATING THE VALUE OF AVOIDED SULFUR DIOXIDE EMISSIONS (STATE- LEVEL)}

The NRC report uses the APEEP provided by Muller et al. (2009) ${ }^{24}$ to estimate the damages of one additional short ton of criteria air pollutants at the county level. The APEEP model differentiates between damages from ground-level emissions, such as emissions from fuel oil and natural gas heaters, and damages from point-source emissions, such as emissions from electric plants.

APPRISE contracted with the model developer to update the model with 2008 data. The 2008 countylevel damage estimates of each additional short ton of ground-level $\mathrm{SO}_{2}$ were weighted by the county population counts from the 2010 census to estimate the average damage values for each state. The state damage estimates for ground-level emissions were used to calculate the benefit of avoided emissions from natural gas, propane, and fuel oil.

Damage estimates of each additional short ton of point-source $\mathrm{SO}_{2}$ emissions were calculated for each NERC region. The EPA eGRID data were used to estimate the annual non-baseload electricity generation for each county using procedures described in the eGRID technical support document. ${ }^{25}$ The county-

\footnotetext{
${ }^{23}$ National Research Council 2010 Hidden Costs of Energy: Unpriced Consequences of Energy Production and Use. National Academy Press, pages 108 and 124.

${ }^{24}$ Muller, N.Z., and R.O. Mendelsohn. 2006. The Air Pollution Emission and Policy Analysis Model (APEEP). Yale University, New Haven, CT. December 2006 [online].

${ }^{25}$ The Emissions \& Generation Resource Integrated Database for 2012 (eGRID2012) Technical Support Document. Environmental Protection Agency. Washington D.C. April, 2012, page 18.
} 
level damage estimates for point-source emissions were weighted by the county-level quantity of annual non-baseload electricity generation to generate averages for each NERC region. For each state, the benefit of avoided emissions from electricity was calculated using the damage estimate for point-source emissions for the NERC region in which the majority of each state's population resides.

The NRC estimated an increase in damages per ton of pollution of approximately $50 \%$ by 2030 due to growth in population combined with increases in the value of a statistical life and other health impact values. ${ }^{26}$ We have applied a similar assumption to our models by incorporating an increase of $1.71 \%$ per year to damage values for $\mathrm{SO}_{2}$ emissions.

Table 4.4 shows cost statistics in a representative state for the target analysis period - 2013 through 2037 - in nominal dollars and 2013 dollars (i.e., discounted by the recommended real discount rate furnished by $\mathrm{OMB}){ }^{27}$

Table 4.4 Social Cost of $\mathrm{SO}_{2}$ (\$ per short ton) By Year (Nominal and 2013 Dollars) - Representative State

\begin{tabular}{|l|c|c|c|c|}
\hline \multirow{2}{*}{ Year } & \multicolumn{2}{|c|}{ Point-Source Emissions } & \multicolumn{2}{c|}{ Ground-Level Emissions } \\
\cline { 2 - 5 } & $\begin{array}{c}\text { \$ Per Short } \\
\text { Ton (Nominal } \\
\text { Value) }\end{array}$ & $\begin{array}{c}\text { \$ Per Short } \\
\text { Ton (2013 } \\
\text { Dollars) }\end{array}$ & $\begin{array}{c}\text { \$ Per Short } \\
\text { Ton (Nominal } \\
\text { Value) }\end{array}$ & $\begin{array}{c}\text { \$ Per Short } \\
\text { Ton (2013 } \\
\text { Dollars) }\end{array}$ \\
\hline 2013 & $\$ 27,402$ & $\$ 27,402$ & $\$ 108,363$ & $\$ 108,363$ \\
\hline 2014 & $\$ 27,871$ & $\$ 27,059$ & $\$ 110,216$ & $\$ 107,006$ \\
\hline 2015 & $\$ 28,347$ & $\$ 26,720$ & $\$ 112,100$ & $\$ 105,665$ \\
\hline 2016 & $\$ 28,832$ & $\$ 26,385$ & $\$ 114,017$ & $\$ 104,342$ \\
\hline 2017 & $\$ 29,325$ & $\$ 26,055$ & $\$ 115,967$ & $\$ 103,035$ \\
\hline Average for first five years & $\$ 28,327$ & $\$ 26,744$ & $\$ 112,133$ & $\$ 105,682$ \\
\hline Average for analysis period & $\$ 30,433$ & $\$ 25,447$ & $\$ 130,469$ & $\$ 95,172$ \\
\hline
\end{tabular}

For a representative state, the avoided emissions per housing unit are listed in Tables 4.1-4.3. The total avoided emissions per housing unit for electricity is multiplied by the dollars per short ton in 2013 dollars for point-source emissions. The total avoided emissions per housing unit for natural gas, propane, and fuel oil is multiplied by the dollars per short ton in 2013 dollars for ground-level emissions. The pointsource and ground-level emissions benefits are combined to estimate the total avoided emission benefit per unit at the state level. Table 4.5 shows that calculation for a representative state. The aggregate emissions benefit for the state is estimated using the average per unit times the number of units served. Table 4.6 shows the calculation for a representative state.

\footnotetext{
${ }^{26}$ National Research Council 2010 Hidden Costs of Energy: Unpriced Consequences of Energy Production and Use. National Academy Press, page 108.

${ }^{27}$ Jeffrey D. Zients M-13-04 Memorandum for the Heads of Departments and Agencies. Executive Office of Management and Budget. January 24, 2013.
} 
Table 4.5 Quantity and Value of Avoided Emissions for $\mathrm{SO}_{2}$ Value per Unit by Fuel Type and Year (2013 Dollars) - Representative State

\begin{tabular}{|l|c|c|c|c|c|c|c|c|}
\hline \multirow{2}{*}{} & \multicolumn{2}{|c|}{$\begin{array}{c}\text { Natural } \\
\text { Gas/Propane }\end{array}$} & \multicolumn{2}{c|}{ Fuel Oil } & \multicolumn{2}{c|}{ Electricity } & \multicolumn{2}{c|}{ All Fuels } \\
\cline { 2 - 10 } Year & $\begin{array}{c}\text { Short } \\
\text { Tons per } \\
\text { Unit }\end{array}$ & $\begin{array}{c}\text { \$ per } \\
\text { Unit }\end{array}$ & $\begin{array}{c}\text { Short } \\
\text { Tons per } \\
\text { Unit }\end{array}$ & $\begin{array}{c}\text { \$ per } \\
\text { Unit }\end{array}$ & $\begin{array}{c}\text { Thons per } \\
\text { Unit }\end{array}$ & $\begin{array}{c}\text { \$ per } \\
\text { Unit }\end{array}$ & $\begin{array}{c}\text { Short } \\
\text { Tons per } \\
\text { Unit }\end{array}$ & $\begin{array}{c}\text { \$ per } \\
\text { Unit }\end{array}$ \\
\hline 2013 & $3.47 \mathrm{E}-06$ & $\$ 0.12$ & $2.43 \mathrm{E}-04$ & $\$ 8.36$ & $2.07 \mathrm{E}-03$ & $\$ 34.26$ & $2.32 \mathrm{E}-03$ & $\$ 42.74$ \\
\hline 2014 & $3.47 \mathrm{E}-06$ & $\$ 0.12$ & $2.43 \mathrm{E}-04$ & $\$ 8.26$ & $2.01 \mathrm{E}-03$ & $\$ 32.87$ & $2.26 \mathrm{E}-03$ & $\$ 41.24$ \\
\hline 2015 & $3.47 \mathrm{E}-06$ & $\$ 0.12$ & $2.43 \mathrm{E}-04$ & $\$ 8.15$ & $1.95 \mathrm{E}-03$ & $\$ 31.53$ & $2.20 \mathrm{E}-03$ & $\$ 39.80$ \\
\hline 2016 & $3.47 \mathrm{E}-06$ & $\$ 0.12$ & $2.43 \mathrm{E}-04$ & $\$ 8.05$ & $1.90 \mathrm{E}-03$ & $\$ 30.25$ & $2.14 \mathrm{E}-03$ & $\$ 38.41$ \\
\hline 2017 & $3.47 \mathrm{E}-06$ & $\$ 0.11$ & $2.43 \mathrm{E}-04$ & $\$ 7.95$ & $1.84 \mathrm{E}-03$ & $\$ 29.02$ & $2.09 \mathrm{E}-03$ & $\$ 37.08$ \\
\hline First five years & $1.73 \mathrm{E}-05$ & $\$ 0.58$ & $1.21 \mathrm{E}-03$ & $\$ 40.78$ & $9.77 \mathrm{E}-03$ & $\$ 157.92$ & $1.10 \mathrm{E}-02$ & $\$ 199.28$ \\
\hline Lifetime & $7.42 \mathrm{E}-05$ & $\$ 2.25$ & $5.32 \mathrm{E}-03$ & $\$ 160.92$ & $2.04 \mathrm{E}-02$ & $\$ 316.17$ & $2.58 \mathrm{E}-02$ & $\$ 479.34$ \\
\hline
\end{tabular}

Table 4.6 Quantity and Value of Avoided Emissions for $\mathrm{SO}_{2}$ Aggregate Value - Representative State

\begin{tabular}{|c|c|c|c|c|c|}
\hline Year & $\begin{array}{l}\text { Housing } \\
\text { Units }\end{array}$ & $\begin{array}{l}\text { Short Tons } \\
\text { Per Unit (All } \\
\text { Fuels) }\end{array}$ & $\begin{array}{l}\text { Aggregate } \\
\text { Short Tons }\end{array}$ & $\begin{array}{c}\text { Value per } \\
\text { Unit (2013 } \\
\text { Dollars - All } \\
\text { Fuels) }\end{array}$ & $\begin{array}{c}\text { Aggregate } \\
\text { Value (2013 } \\
\text { Dollars - All } \\
\text { Fuels) }\end{array}$ \\
\hline 2013 & 14,417 & $2.32 \mathrm{E}-03$ & 33.38 & $\$ 42.74$ & $\$ 616,199$ \\
\hline 2014 & 14,417 & $2.26 \mathrm{E}-03$ & 32.53 & $\$ 41.24$ & $\$ 594,582$ \\
\hline 2015 & 14,417 & $2.20 \mathrm{E}-03$ & 31.70 & $\$ 39.80$ & $\$ 573,800$ \\
\hline 2016 & 14,417 & $2.14 \mathrm{E}-03$ & 30.90 & $\$ 38.41$ & $\$ 553,821$ \\
\hline 2017 & 14,417 & $2.09 \mathrm{E}-03$ & 30.12 & $\$ 37.08$ & $\$ 534,612$ \\
\hline First five years & 14,417 & $1.10 \mathrm{E}-02$ & 158.62 & $\$ 199.28$ & $\$ 2,873,014$ \\
\hline Lifetime & 14,417 & $2.58 \mathrm{E}-02$ & 372.03 & $\$ 479.34$ & $\$ 6,910,639$ \\
\hline
\end{tabular}




\subsection{NATIONAL TOTALS}

The state-level analysis furnishes information on the aggregate avoided emissions, the aggregate emissions benefit, and the number of units served for each state. Those are cumulated to develop a national aggregate value of avoided emissions. Table 4.7 shows the quantity of avoided emissions by fuel type. Table 4.8 shows the value of avoided emissions by fuel type. The analysis shows that if the 2010 WAP program were implemented in 2013, it would be expected to reduce $\mathrm{SO}_{2}$ emissions by 10,531 short tons (Table 4.7) at a lifetime value of $\$ 286,819,004$ (Table 4.8). Most of the avoided emissions accrue from the reductions in the use of fuel oil and electricity.

Table 4.7 Quantity of Avoided Emissions for $\mathrm{SO}_{2}$ National Aggregate Total by Fuel Type and Year

\begin{tabular}{|l|c|c|c|c|}
\hline \multirow{2}{*}{ Year } & \multicolumn{3}{|c|}{ Avoided Emissions (Short Tons of $\mathbf{S O}_{2}$ ) } \\
\cline { 2 - 5 } & $\begin{array}{c}\text { Natural } \\
\text { Gas/Propane }\end{array}$ & Fuel Oil & Electricity & All Fuels \\
\hline 2013 & 0.76 & 127.11 & 686.62 & 814.50 \\
\hline 2014 & 0.76 & 127.11 & 667.05 & 794.93 \\
\hline 2015 & 0.76 & 127.11 & 648.04 & 775.92 \\
\hline 2016 & 0.76 & 127.11 & 629.57 & 757.45 \\
\hline 2017 & 0.76 & 127.11 & 611.63 & 739.51 \\
\hline First five years & 3.82 & 635.57 & $3,242.91$ & $3,882.31$ \\
\hline Lifetime & 15.99 & $2,651.88$ & $7,863.09$ & $10,530.96$ \\
\hline
\end{tabular}

Table 4.8 Value of Avoided Emissions for $\mathrm{SO}_{2}$ National Aggregate Total by Fuel Type and Year

\begin{tabular}{|l|c|c|c|c|}
\hline \multirow{2}{*}{ Year } & \multicolumn{3}{|c|}{ Avoided Emissions (2013 Dollars) } \\
\cline { 2 - 5 } & $\begin{array}{c}\text { Natural } \\
\text { Gas/Propane }\end{array}$ & Fuel Oil & Electricity & All Fuels \\
\hline 2013 & $\$ 38,180$ & $\$ 7,039,926$ & $\$ 15,235,165$ & $\$ 22,313,271$ \\
\hline 2014 & $\$ 37,702$ & $\$ 6,951,756$ & $\$ 14,615,591$ & $\$ 21,605,049$ \\
\hline 2015 & $\$ 37,230$ & $\$ 6,864,690$ & $\$ 14,021,215$ & $\$ 20,923,135$ \\
\hline 2016 & $\$ 36,763$ & $\$ 6,778,715$ & $\$ 13,451,010$ & $\$ 20,266,488$ \\
\hline 2017 & $\$ 36,303$ & $\$ 6,693,817$ & $\$ 12,903,992$ & $\$ 19,634,113$ \\
\hline First five years & $\$ 186,178$ & $\$ 34,328,904$ & $\$ 70,226,975$ & $\$ 104,742,054$ \\
\hline Lifetime & $\$ 703,590$ & $\$ 126,795,909$ & $\$ 159,319,505$ & $\$ 286,819,004$ \\
\hline
\end{tabular}

Table 4.9 shows the calculation for the average amount of avoided emissions and the average value per housing unit served by the WAP program. The estimated avoided emissions per housing unit at the national level is 0.0317 short tons with a lifetime value of $\$ 864$. 
Table 4.9 Quantity and Value of Avoided Emissions for $\mathrm{SO}_{2}$ Per Housing Unit - National

\begin{tabular}{|c|c|c|c|c|c|}
\hline Year & Units & $\begin{array}{l}\text { Aggregate } \\
\text { Short Tons }\end{array}$ & $\begin{array}{c}\text { Short Tons } \\
\text { Per Unit (All } \\
\text { Fuels) }\end{array}$ & $\begin{array}{c}\text { Aggregate } \\
\text { Value (2013 } \\
\text { Dollars - All } \\
\text { Fuels) }\end{array}$ & $\begin{array}{l}\text { Value Per } \\
\text { Housing Unit } \\
\text { (2013 Dollars } \\
\text { - All Fuels) }\end{array}$ \\
\hline 2013 & 331,866 & 814 & 0.0025 & $\$ 22,313,271$ & $\$ 67.24$ \\
\hline 2014 & 331,866 & 795 & 0.0024 & $\$ 21,605,049$ & $\$ 65.10$ \\
\hline 2015 & 331,866 & 776 & 0.0023 & $\$ 20,923,135$ & $\$ 63.05$ \\
\hline 2016 & 331,866 & 757 & 0.0023 & $\$ 20,266,488$ & $\$ 61.07$ \\
\hline 2017 & 331,866 & 740 & 0.0022 & $\$ 19,634,113$ & $\$ 59.16$ \\
\hline First five years & 331,866 & 3,882 & 0.0117 & $\$ 104,742,054$ & $\$ 315.62$ \\
\hline Lifetime & 331,866 & 10,531 & 0.0317 & $\$ 286,819,004$ & $\$ 864.26$ \\
\hline
\end{tabular}





\section{BENEFITS FROM NITROGEN OXIDE GAS EMISSIONS REDUCTIONS}

The estimates of avoided $\mathrm{NO}_{\mathrm{x}}$ are made separately for natural gas and propane, fuel oil, and electricity. Each type of fuel has a different amount of avoided $\mathrm{NO}_{\mathrm{x}}$ per unit of energy savings. In addition, for electricity, the amount of avoided $\mathrm{NO}_{\mathrm{x}}$ varies by geographic region because of differences in the $\mathrm{NO}_{\mathrm{x}}$ emissions rates for generation plants.

\subsection{NATURAL GAS AND PROPANE}

The EPA furnished an estimate of the $\mathrm{NO}_{\mathrm{x}}$ emissions factor from natural gas combustion in boilers and furnaces in AP-42. ${ }^{28}$ Emissions are estimated to be 94 pounds of $\mathrm{NO}_{\mathrm{x}}$ per $10^{6}$ standard cubic feet of natural gas $\left(4.59 \times 10^{-5}\right.$ short tons per MMBtu).

Table 5.1 shows how avoided emissions were computed for one state studied in the WAP evaluation. The calculation for the representative state shows that the average projected savings per unit in the first program year would be 118.56 therms and the avoided emissions per unit would be $5.44 \times 10^{-4}$ short tons. The projected lifetime savings would be 2,535.80 therms and the lifetime avoided emissions would be $1.16 \times 10^{-2}$ short tons.

Note that the installed measures vary in terms of their estimated lifetime. For measures that affect natural gas and propane usage, the lifetime varies between 13 years for a setback thermostat to 25 years for insulation. So, the average therms of savings per unit are lower in some of the later years.

Table 5.1 Avoided Emissions for NO$_{x}$ Natural Gas and Propane Usage Reductions - Representative State

\begin{tabular}{|l|c|c|c|c|}
\hline Year & $\begin{array}{c}\text { Savings per } \\
\text { Housing Unit } \\
\text { (therms) }\end{array}$ & $\begin{array}{c}\text { Savings per } \\
\text { Housing Unit } \\
\text { (MMBtu) }\end{array}$ & $\begin{array}{c}\text { Rate (Short } \\
\text { Tons/MMBtu) }\end{array}$ & $\begin{array}{c}\text { Short Tons per } \\
\text { Housing Unit }\end{array}$ \\
\hline First Year & 118.56 & 11.86 & $4.59 \mathrm{E}-05$ & $5.44 \mathrm{E}-04$ \\
\hline Lifetime & $2,535.80$ & 253.58 & $4.59 \mathrm{E}-05$ & $1.16 \mathrm{E}-02$ \\
\hline
\end{tabular}

For this calculation, it was assumed that the greenhouse gas emission rates for propane were the same as the rates for natural gas. While that is likely to be a reliable assumption for combustion, it is possible that the process for producing propane has different upstream emissions. However, since propane is a small part of the total energy savings associated with the program (12.4\% of savings in the example state), the potential bias is small.

\subsection{FUEL OIL}

The fuel oil $\mathrm{NO}_{\mathrm{x}}$ emissions rate was computed using the EPA estimated $\mathrm{NO}_{\mathrm{x}}$ emissions factor from AP$42^{30}$. Compilation of Air Pollutant Emissions. ${ }^{31}$ The EPA factor is 18 pounds per $10^{3}$ gallons of residential fuel oil $\left(6.49 \times 10^{-5}\right.$ short tons per MMBtu).

\footnotetext{
${ }^{28}$ AP 42, Fifth Edition, Compilation of Air Pollutant Emission Factors, Volume 1: Stationary Point and Area Sources, Chapter 1: External Combustion Sources. http://www.epa.gov/ttnchie1/ap42/ch01/ 1.4 Natural Gas Combustion Final Section - Supplement D, July 1998. http://www.epa.gov/ttn/chief/ap42/ch01/final/c01s04.pdf page 1.4-5.

${ }^{29}$ The savings per housing unit for any state is the projected aggregate natural gas and propane savings from housing units that use one of those fuels divided by the total number of housing units served by the program in that state.
} 
Table 5.2 shows how avoided emissions were computed for one state studied in the WAP evaluation. The calculation for the representative state shows that the average projected savings per unit in the first program year would be 6.84 gallons and the avoided emissions per unit would be $6.16 \times 10^{-5}$ short tons. The projected lifetime savings would be 149.99 gallons and the lifetime avoided emissions would be 1.35 x $10^{-3}$ short tons.

Note that the installed measures vary in terms of their estimated lifetime. For measures that affect fuel oil, the lifetime varies between 13 years for a setback thermostat to 25 years for insulation. So, the average savings per unit are lower in some of the later years.

Table 5.2 Avoided Emissions for $\mathrm{NO}_{\mathrm{x}}$ Fuel Oil Usage Reductions - Representative State

\begin{tabular}{|l|c|c|c|c|}
\hline Year & $\begin{array}{c}\text { Savings per } \\
\text { Housing Unit } \\
\text { (Gallons) }^{\mathbf{3 2}}\end{array}$ & $\begin{array}{c}\text { Savings per } \\
\text { Housing Unit } \\
\text { (MMBtu) }\end{array}$ & $\begin{array}{c}\text { Rate (Short } \\
\text { Tons/MMBtu) }\end{array}$ & $\begin{array}{c}\text { Short Tons per } \\
\text { Housing Unit }\end{array}$ \\
\hline First Year & 6.84 & 0.95 & $6.49 \mathrm{E}-05$ & $6.16 \mathrm{E}-05$ \\
\hline Lifetime & 149.99 & 20.80 & $6.49 \mathrm{E}-05$ & $1.35 \mathrm{E}-03$ \\
\hline
\end{tabular}

\subsection{ELECTRICITY}

The estimate of the emissions rates for Nitrogen Oxides for electricity is based on reported data for the eGRID region in which the state is located. EPA's eGRID emission summary tables were released in 2012. ${ }^{33}$ These tables furnish estimates of baseload and non-baseload emission rates for each NERC region. For this analysis, we used the non-baseload emission rates as recommended by EPA. ${ }^{34}$

These tables furnish emission rates for $\mathrm{NO}_{\mathrm{x}}$ per $\mathrm{kWh}$ generated at the source. We adjusted the $\mathrm{kWh}$ savings from the WAP evaluation to account for transmission losses. These estimates are provided in the EPA eGRID summary tables. ${ }^{35}$

Table 5.3 shows how avoided emissions were computed for one state studied in the WAP evaluation. The calculation for the representative state shows that the average projected savings per unit in the first program year would be $678 \mathrm{kWh}$ and the avoided emissions per unit would be $1.07 \times 10^{-3}$ short tons. The projected lifetime savings would be $7,874 \mathrm{kWh}$ and the lifetime avoided emissions would be $1.06 \times 10^{-2}$ short tons.

Note that the installed measures vary in terms of their estimated lifetime. For measures that affect electricity, the lifetime varies between 7 years for lighting and 25 years for insulation. So, the average savings per unit are lower in some of the later years.

\footnotetext{
${ }^{30}$ AP42, Compilation of Air Pollution Emission Factors, Volume 1: Stationary Point and Area Sources, Chapter 1: External Combustion Sources. http://www.epa.gov/ttnchie1/ap42/ch01/ Section 1.3 Fuel Oil Combustion Final Section - Supplement E September 1999, corrected May 2010. http://www.epa.gov/ttn/chief/ap42/ch01/final/c01s03.pdf, page 1.3-12.

31 29. N. F. Suprenant, et al., Emissions Assessment Of Conventional Stationary Combustion Systems, Volume I: Gas And Oil Fired Residential Heating Sources, EPA-600/7-79-029b, U. S. Environmental Protection Agency, Washington, DC, May 1979.

32 The savings per housing unit for any state is the projected aggregate fuel oil savings from housing units with fuel oil main heat divided by the total number of housing units served by the program in that state.

${ }^{33}$ EPA eGRID2012 Version 1.0 Year 2009 Summary Tables. Environmental Protection Agency. Washington D.C. April, 2012.

${ }^{34}$ Art Diem and Cristina Quiroz, How to use eGRID for Carbon Footprinting Electricity Purchases in Greenhouse Gas Emission Inventories. Environmental Protection Agency. Washington D.C. Page 10-11. July 2012.

${ }^{35}$ EPA eGRID2012 Version 1.0 Year 2009 Summary Tables. Environmental Protection Agency. Washington D.C. April, 2012. Pages $7 \& 9$.
} 
The NRC observed that emission rates of $\mathrm{NO}_{\mathrm{x}}$ from power plants are expected to decline over time due to increased regulation and costs. The report recommended explicitly accounting for those expected reductions in emissions and provided estimates of 2030 emissions reductions varying by pollutant and power plant fuel. ${ }^{36}$ We chose to apply a rough estimate of a $50 \%$ emissions reduction over the analysis period of 2013 to 2037 . This translates to an annual reduction of $2.85 \%$ to the rate of $\mathrm{NO}_{\mathrm{x}}$ emissions from electricity generation in our models.

Table 5.3 Avoided Emissions for $\mathrm{NO}_{\mathrm{x}}$ Electricity Usage Reductions - Representative State

\begin{tabular}{|l|c|c|c|c|c|}
\hline Year & $\begin{array}{c}\text { Savings per } \\
\text { Housing Unit } \\
\text { (kWh Site) }\end{array}$ & $\begin{array}{c}\text { Savings per } \\
\text { Housing Unit } \\
\text { (kWh Source) }\end{array}$ & $\begin{array}{c}\text { Savings per } \\
\text { Housing Unit } \\
\text { (MMBtu } \\
\text { Source) }\end{array}$ & $\begin{array}{c}\text { Rate (Short } \\
\text { Tons/MMBtu) }\end{array}$ & $\begin{array}{c}\text { Short Tons per } \\
\text { Housing Unit }\end{array}$ \\
\hline 2013 & 678 & 720 & 2.46 & $4.36 \mathrm{E}-04$ & $1.07 \mathrm{E}-03$ \\
\hline 2014 & 678 & 720 & 2.46 & $4.23 \mathrm{E}-04$ & $1.04 \mathrm{E}-03$ \\
\hline 2015 & 678 & 720 & 2.46 & $4.11 \mathrm{E}-04$ & $1.01 \mathrm{E}-03$ \\
\hline 2016 & 678 & 720 & 2.46 & $4.00 \mathrm{E}-04$ & $9.82 \mathrm{E}-04$ \\
\hline 2017 & 678 & 720 & 2.46 & $3.88 \mathrm{E}-04$ & $9.54 \mathrm{E}-04$ \\
\hline First five years & 3,391 & 3,600 & 12.28 & $4.12 \mathrm{E}-04$ & $5.06 \mathrm{E}-03$ \\
\hline Lifetime & 7,874 & 8,361 & 28.53 & $3.70 \mathrm{E}-04$ & $1.06 \mathrm{E}-02$ \\
\hline
\end{tabular}

\subsection{ESTIMATING THE VALUE OF AVOIDED NITROGEN OXIDE EMISSIONS (STATE- LEVEL)}

The NRC report uses the APEEP provided by Muller et al. (2009) ${ }^{37}$ to estimate the damages of one additional short ton of criteria air pollutants at the county level. The APEEP model differentiates between damages from ground-level emissions, such as emissions from fuel oil and natural gas heaters, and damages from point-source emissions, such as emissions from electric plants.

APPRISE contracted with the model developer to update the model with 2008 data. The 2008 countylevel damage estimates of each additional short ton of ground-level $\mathrm{NO}_{\mathrm{x}}$ were weighted by the county population counts from the 2010 census to estimate the average damage values for each state. The state damage estimates for ground-level emissions were used to calculate the benefit of avoided emissions from natural gas, propane, and fuel oil.

Damage estimates of each additional short ton of point-source $\mathrm{NO}_{\mathrm{x}}$ emissions were calculated for each NERC region. The EPA eGRID data were used to estimate the annual non-baseload electricity generation for each county using procedures described in the eGRID technical support document. ${ }^{38}$ The countylevel damage estimates for point-source emissions were weighted by the county-level quantity of annual non-baseload electricity generation to generate averages for each NERC region. For each state, the benefit of avoided emissions from electricity was calculated using the damage estimate for point-source emissions for the NERC region in which the majority of each state's population resides.

\footnotetext{
${ }^{36}$ National Research Council 2010 Hidden Costs of Energy: Unpriced Consequences of Energy Production and Use. National Academy Press, pages 108 and 124.

${ }^{37}$ Muller, N.Z., and R.O. Mendelsohn. 2006. The Air Pollution Emission and Policy Analysis Model (APEEP). Yale University, New Haven, CT. December 2006 [online].

${ }^{38}$ The Emissions \& Generation Resource Integrated Database for 2012 (eGrid2012) Technical Support Document. Environmental Protection Agency. Washington D.C. April, 2012, page 18.
} 
The NRC estimated an increase in damages per ton of pollution of approximately $50 \%$ by 2030 due to growth in population combined with increases in the value of a statistical life and other health impact values. ${ }^{39}$ We have applied a similar assumption to our models by incorporating an increase of $1.71 \%$ per year to damage values for $\mathrm{SO}_{2}, \mathrm{NO}_{\mathrm{X}}, \mathrm{PM} 2.5$, and VOC emissions.

Table 5.4 shows cost statistics in a representative state for the target analysis period - 2013 through 2037 - in nominal dollars and 2013 dollars (i.e., discounted by the recommended real discount rate furnished by $\mathrm{OMB}){ }^{40}$

Table 5.4 Social Cost of $\mathrm{NO}_{\mathrm{x}}$ (\$ per short ton) By Year (Nominal and 2013 Dollars) - Representative State

\begin{tabular}{|l|c|c|c|c|}
\hline \multirow{2}{*}{ Year } & \multicolumn{2}{|c|}{ Point-Source Emissions } & \multicolumn{2}{c|}{ Ground-Level Emissions } \\
\cline { 2 - 5 } & $\begin{array}{c}\text { \$ Per Short } \\
\text { Ton (Nominal } \\
\text { Value) }\end{array}$ & $\begin{array}{c}\text { \$ Per Short } \\
\text { Ton (2013 } \\
\text { Dollars) }\end{array}$ & $\begin{array}{c}\text { \$ Per Short } \\
\text { Ton (Nominal } \\
\text { Value) }\end{array}$ & $\begin{array}{c}\text { \$ Per Short } \\
\text { Ton (2013 } \\
\text { Dollars) }\end{array}$ \\
\hline 2013 & $\$ 5,566$ & $\$ 5,566$ & $\$ 22,361$ & $\$ 22,361$ \\
\hline 2014 & $\$ 5,661$ & $\$ 5,496$ & $\$ 22,743$ & $\$ 22,081$ \\
\hline 2015 & $\$ 5,758$ & $\$ 5,428$ & $\$ 23,132$ & $\$ 21,804$ \\
\hline 2016 & $\$ 5,857$ & $\$ 5,360$ & $\$ 23,527$ & $\$ 21,531$ \\
\hline 2017 & $\$ 5,957$ & $\$ 5,292$ & $\$ 23,930$ & $\$ 21,261$ \\
\hline Average for first five years & $\$ 5,754$ & $\$ 5,432$ & $\$ 23,139$ & $\$ 21,807$ \\
\hline Average for analysis period & $\$ 6,182$ & $\$ 5,169$ & $\$ 26,862$ & $\$ 19,668$ \\
\hline
\end{tabular}

For a representative state, the avoided emissions per housing unit are listed in Tables 5.1-5.3. The total avoided emissions per housing unit for electricity is multiplied by the dollars per short ton in 2013 dollars for point-source emissions. The total avoided emissions per housing unit for natural gas, propane, and fuel oil is multiplied by the dollars per short ton in 2013 dollars for ground-level emissions. The pointsource and ground-level emissions benefits are combined to estimate the total avoided emission benefit per unit at the state level. Table 5.5 shows that calculation for a representative state. The aggregate emissions benefit for the state is estimated using the average per unit times the number of units served. Table 5.6 shows the calculation for a representative state.

\footnotetext{
${ }^{39}$ National Research Council 2010 Hidden Costs of Energy: Unpriced Consequences of Energy Production and Use. National Academy Press, page 108.

${ }^{40}$ Jeffrey D. Zients M-13-04 Memorandum for the Heads of Departments and Agencies. Executive Office of Management and Budget. January 24, 2013.
} 
Table 5.5 Quantity and Value of Avoided Emissions for $\mathrm{NO}_{\mathrm{x}}$ Value per Unit by Fuel Type and Year (2013 Dollars) - Representative State

\begin{tabular}{|l|c|c|c|c|c|c|c|c|}
\hline \multirow{2}{*}{ Year } & \multicolumn{2}{|c|}{ Natural Gas/Propane } & \multicolumn{2}{|c|}{ Fuel Oil } & \multicolumn{2}{c|}{ Electricity } & \multicolumn{2}{c|}{ All Fuels } \\
\cline { 2 - 10 } & $\begin{array}{c}\text { Short } \\
\text { Tons per } \\
\text { Unit }\end{array}$ & $\begin{array}{c}\text { \$ per } \\
\text { Unit }\end{array}$ & $\begin{array}{c}\text { Short } \\
\text { Tons per } \\
\text { Unit }\end{array}$ & $\begin{array}{c}\text { \$ per } \\
\text { Unit }\end{array}$ & $\begin{array}{c}\text { Short } \\
\text { Tons per } \\
\text { Unit }\end{array}$ & $\begin{array}{c}\text { \$ per } \\
\text { Unit }\end{array}$ & $\begin{array}{c}\text { Short Tons } \\
\text { per Unit }\end{array}$ & \$ per Unit \\
\hline 2013 & $5.44 \mathrm{E}-04$ & $\$ 8.26$ & $6.16 \mathrm{E}-05$ & $\$ 0.94$ & $1.07 \mathrm{E}-03$ & $\$ 7.05$ & $1.68 \mathrm{E}-03$ & $\$ 16.24$ \\
\hline 2014 & $5.44 \mathrm{E}-04$ & $\$ 8.15$ & $6.16 \mathrm{E}-05$ & $\$ 0.92$ & $1.04 \mathrm{E}-03$ & $\$ 6.76$ & $1.65 \mathrm{E}-03$ & $\$ 15.84$ \\
\hline 2015 & $5.44 \mathrm{E}-04$ & $\$ 8.05$ & $6.16 \mathrm{E}-05$ & $\$ 0.91$ & $1.01 \mathrm{E}-03$ & $\$ 6.48$ & $1.62 \mathrm{E}-03$ & $\$ 15.45$ \\
\hline 2016 & $5.44 \mathrm{E}-04$ & $\$ 7.95$ & $6.16 \mathrm{E}-05$ & $\$ 0.90$ & $9.82 \mathrm{E}-04$ & $\$ 6.22$ & $1.59 \mathrm{E}-03$ & $\$ 15.07$ \\
\hline 2017 & $5.44 \mathrm{E}-04$ & $\$ 7.85$ & $6.16 \mathrm{E}-05$ & $\$ 0.89$ & $9.54 \mathrm{E}-04$ & $\$ 5.97$ & $1.56 \mathrm{E}-03$ & $\$ 14.71$ \\
\hline First five years & $2.72 \mathrm{E}-03$ & $\$ 40.27$ & $3.08 \mathrm{E}-04$ & $\$ 4.56$ & $5.06 \mathrm{E}-03$ & $\$ 32.48$ & $8.08 \mathrm{E}-03$ & $\$ 77.31$ \\
\hline Lifetime & $1.16 \mathrm{E}-02$ & $\$ 155.43$ & $1.35 \mathrm{E}-03$ & $\$ 18.00$ & $1.06 \mathrm{E}-02$ & $\$ 65.03$ & $2.35 \mathrm{E}-02$ & $\$ 238.45$ \\
\hline
\end{tabular}

Table 5.6 Quantity and Value of Avoided Emissions for $\mathrm{NO}_{\mathrm{x}}$ Aggregate Value - Representative State

\begin{tabular}{|l|c|c|c|c|c|}
\hline Year & Housing & $\begin{array}{c}\text { Short Tons } \\
\text { Per Unit (All } \\
\text { Fuels) }\end{array}$ & $\begin{array}{c}\text { Aggregate } \\
\text { Short Tons }\end{array}$ & $\begin{array}{c}\text { Value per } \\
\text { Unit (2013 } \\
\text { Dollars - All } \\
\text { Fuels) }\end{array}$ & $\begin{array}{c}\text { Aggregate } \\
\text { Value (2013 } \\
\text { Dollars - All } \\
\text { Fuels) }\end{array}$ \\
\hline 2013 & 14,417 & $1.68 \mathrm{E}-03$ & 24.16 & $\$ 16.24$ & $\$ 234,122$ \\
\hline 2014 & 14,417 & $1.65 \mathrm{E}-03$ & 23.72 & $\$ 15.84$ & $\$ 228,331$ \\
\hline 2015 & 14,417 & $1.62 \mathrm{E}-03$ & 23.30 & $\$ 15.45$ & $\$ 222,728$ \\
\hline 2016 & 14,417 & $1.59 \mathrm{E}-03$ & 22.88 & $\$ 15.07$ & $\$ 217,308$ \\
\hline 2017 & 14,417 & $1.56 \mathrm{E}-03$ & 22.48 & $\$ 14.71$ & $\$ 212,062$ \\
\hline First five years & 14,417 & $8.08 \mathrm{E}-03$ & 116.54 & $\$ 77.31$ & $\$ 1,114,550$ \\
\hline Lifetime & 14,417 & $2.35 \mathrm{E}-02$ & 339.38 & $\$ 238.45$ & $\$ 3,437,739$ \\
\hline
\end{tabular}

\subsection{NATIONAL TOTALS}

The state-level analysis furnishes information on the aggregate avoided emissions, the aggregate emissions benefit, and the number of units served for each state. Those are cumulated to develop a national aggregate value of avoided emissions. Table 5.7 shows the quantity of avoided emissions by fuel type. Table 5.8 shows the value of avoided emissions by fuel type. The analysis shows that if the 2010 WAP program were implemented in 2013, it would be expected to reduce $\mathrm{NO}_{\mathrm{x}}$ emissions by 5,834 short tons (Table 5.7) at a lifetime value of $\$ 52,179,316$ (Table 5.8). 
Table 5.7 Quantity of Avoided Emissions for NO $_{\mathbf{x}}$ National Aggregate Total by Fuel Type and Year

\begin{tabular}{|l|c|c|c|c|}
\hline \multirow{2}{*}{ Year } & \multicolumn{3}{|c|}{ Avoided Emissions (Short Tons of NO $)$} \\
\cline { 2 - 5 } & $\begin{array}{c}\text { Natural } \\
\text { Gas/Propane }\end{array}$ & Fuel Oil & Electricity & \multirow{2}{*}{ All Fuels } \\
\hline 2013 & 119.84 & 32.23 & 230.95 & 383.02 \\
\hline 2014 & 119.84 & 32.23 & 224.37 & 376.44 \\
\hline 2015 & 119.84 & 32.23 & 217.98 & 370.04 \\
\hline 2016 & 119.84 & 32.23 & 211.76 & 363.83 \\
\hline 2017 & 119.84 & 32.23 & 205.73 & 357.79 \\
\hline First five years & 599.19 & 161.13 & $1,090.79$ & $1,851.12$ \\
\hline Lifetime & $2,504.67$ & 672.31 & $2,657.43$ & $5,834.40$ \\
\hline
\end{tabular}

Table 5.8 Value of Avoided Emissions for $\mathrm{NO}_{\mathrm{x}}$ National Aggregate Total by Fuel Type and Year

\begin{tabular}{|l|c|c|c|c|}
\hline \multirow{2}{*}{ Year } & \multicolumn{3}{|c|}{ Avoided Emissions (2013 Dollars) } \\
\cline { 2 - 5 } & $\begin{array}{c}\text { Natural } \\
\text { Gas/Propane }\end{array}$ & Fuel Oil & Electricity & All Fuels \\
\hline 2013 & $\$ 1,868,045$ & $\$ 304,652$ & $\$ 1,166,718$ & $\$ 3,339,415$ \\
\hline 2014 & $\$ 1,844,649$ & $\$ 300,837$ & $\$ 1,119,271$ & $\$ 3,264,756$ \\
\hline 2015 & $\$ 1,821,546$ & $\$ 297,069$ & $\$ 1,073,753$ & $\$ 3,192,368$ \\
\hline 2016 & $\$ 1,798,732$ & $\$ 293,348$ & $\$ 1,030,086$ & $\$ 3,122,167$ \\
\hline 2017 & $\$ 1,776,205$ & $\$ 289,675$ & $\$ 988,196$ & $\$ 3,054,075$ \\
\hline First five years & $\$ 9,109,176$ & $\$ 1,485,581$ & $\$ 5,378,024$ & $\$ 15,972,782$ \\
\hline Lifetime & $\$ 34,459,893$ & $\$ 5,491,416$ & $\$ 12,228,007$ & $\$ 52,179,316$ \\
\hline
\end{tabular}


Table 5.9 shows the calculation for the average amount of avoided emissions and the average value per housing unit served by the WAP program. The estimated avoided emissions per housing unit at the national level is 0.0176 short tons with a lifetime value of $\$ 157$.

Table 5.9 Quantity and Value of Avoided Emissions for $\mathrm{NO}_{\mathrm{x}}$ Per Housing Unit - National

\begin{tabular}{|c|c|c|c|c|c|}
\hline Year & Units & $\begin{array}{l}\text { Aggregate } \\
\text { Short Tons }\end{array}$ & $\begin{array}{c}\text { Short Tons } \\
\text { Per Unit (All } \\
\text { Fuels) }\end{array}$ & $\begin{array}{c}\text { Aggregate } \\
\text { Value (2013 } \\
\text { Dollars - All } \\
\text { Fuels) }\end{array}$ & $\begin{array}{c}\text { Value Per } \\
\text { Housing Unit } \\
\text { (2013 Dollars } \\
\text { - All Fuels) }\end{array}$ \\
\hline 2013 & 331,866 & 383.02 & 0.0012 & $\$ 3,339,415$ & $\$ 10.06$ \\
\hline 2014 & 331,866 & 376.44 & 0.0011 & $\$ 3,264,756$ & $\$ 9.84$ \\
\hline 2015 & 331,866 & 370.04 & 0.0011 & $\$ 3,192,368$ & $\$ 9.62$ \\
\hline 2016 & 331,866 & 363.83 & 0.0011 & $\$ 3,122,167$ & $\$ 9.41$ \\
\hline 2017 & 331,866 & 357.79 & 0.0011 & $\$ 3,054,075$ & $\$ 9.20$ \\
\hline First five years & 331,866 & $1,851.12$ & 0.0056 & $\$ 15,972,782$ & $\$ 48.13$ \\
\hline Lifetime & 331,866 & $5,834.40$ & 0.0176 & $\$ 52,179,316$ & $\$ 157.23$ \\
\hline
\end{tabular}





\section{BENEFITS FROM PM 2.5 EMISSIONS REDUCTIONS}

The estimates of avoided PM 2.5 are made separately for natural gas and propane, fuel oil, and electricity. Each type of fuel has a different amount of avoided PM 2.5 per unit of energy savings. In addition, for electricity, the amount of avoided PM 2.5 varies by geographic region because of differences in the PM 2.5 emissions rates for generation plants.

\subsection{NATURAL GAS AND PROPANE}

The EPA furnished an estimate of the PM 2.5 emissions factor from natural gas combustion in boilers and furnaces in AP-42. ${ }^{41}$ Emissions are estimated to be 1.9 pounds of PM 2.5 per $10^{6}$ standard cubic feet of natural gas $\left(9.27 \times 10^{-7}\right.$ short tons per MMBtu).

Table 6.1 shows how avoided emissions were computed for one state studied in the WAP evaluation. The calculation for the representative state shows that the average projected savings per unit in the first program year would be 118.56 therms and the avoided emissions per unit would be $1.10 \times 10^{-5}$ short tons. The projected lifetime savings would be 2,535.80 therms and the lifetime avoided emissions would be $2.34 \times 10^{-4}$ short tons.

Note that the installed measures vary in terms of their estimated lifetime. For measures that affect natural gas and propane usage, the lifetime varies between 13 years for a setback thermostat to 25 years for insulation. So, the average therms of savings per unit are lower in some of the later years.

Table 6.1 Avoided Emissions for PM 2.5 Natural Gas and Propane Usage Reductions - Representative State

\begin{tabular}{|l|c|c|c|c|}
\hline Year & $\begin{array}{c}\text { Savings per } \\
\text { Housing Unit } \\
\text { (therms) }^{\mathbf{4 2}}\end{array}$ & $\begin{array}{c}\text { Savings per } \\
\text { Housing Unit } \\
\text { (MMBtu) }\end{array}$ & $\begin{array}{c}\text { Rate (Short } \\
\text { Tons/MMBtu) }\end{array}$ & $\begin{array}{c}\text { Short Tons per } \\
\text { Housing Unit }\end{array}$ \\
\hline First Year & 118.56 & 11.86 & $9.27 \mathrm{E}-07$ & $1.10 \mathrm{E}-05$ \\
\hline Lifetime & $2,535.80$ & 253.58 & $9.27 \mathrm{E}-07$ & $2.35 \mathrm{E}-04$ \\
\hline
\end{tabular}

For this calculation, it was assumed that the greenhouse gas emission rates for propane were the same as the rates for natural gas. While that is likely to be a reliable assumption for combustion, it is possible that the process for producing propane has different upstream emissions. However, since propane is a small part of the total energy savings associated with the program (12.4\% of savings in the example state), the potential bias is small.

\subsection{FUEL OIL}

The fuel oil PM 2.5 emissions rate was computed using the EPA estimated PM 2.5 emissions factor from AP- $42^{43}$, Compilation of Air Pollutant Emissions. ${ }^{44}$ The EPA factor is 0.4 pounds of PM 2.5 per $10^{3}$ gallons of residential fuel oil (1.44 × $10^{-6}$ short tons per MMBtu).

\footnotetext{
${ }^{41}$ AP 42, Fifth Edition, Compilation of Air Pollutant Emission Factors, Volume 1: Stationary Point and Area Sources, Chapter 1: External Combustion Sources. http://www.epa.gov/ttnchie1/ap42/ch01/ 1.4 Natural Gas Combustion Final Section - Supplement D, July 1998. http://www.epa.gov/ttn/chief/ap42/ch01/final/c01s04.pdf page 1.4-6.

${ }^{42}$ The savings per housing unit for any state is the projected aggregate natural gas and propane savings from housing units that use one of those fuels divided by the total number of housing units served by the program in that state.
} 
Table 6.2 shows how avoided emissions were computed for one state studied in the WAP evaluation. The calculation for the representative state shows that the average projected savings per unit in the first program year would be 6.84 gallons and the avoided emissions per unit would be $1.37 \times 10^{-6}$ short tons. The projected lifetime savings would be 149.99 gallons and the lifetime avoided emissions would be 3.00 x $10^{-5}$ short tons.

Note that the installed measures vary in terms of their estimated lifetime. For measures that affect fuel oil, the lifetime varies between 13 years for a setback thermostat to 25 years for insulation. So, the average savings per unit are lower in some of the later years.

Table 6.2 Avoided Emissions for PM 2.5 Fuel Oil Usage Reductions - Representative State

\begin{tabular}{|l|c|c|c|c|}
\hline Year & $\begin{array}{c}\text { Savings per } \\
\text { Housing Unit } \\
\text { (Gallons) }\end{array}$ & $\begin{array}{c}\text { Savings per } \\
\text { Housing Unit } \\
\text { (MMBtu) }\end{array}$ & $\begin{array}{c}\text { Rate (Short } \\
\text { Tons/MMBtu) }\end{array}$ & $\begin{array}{c}\text { Short Tons per } \\
\text { Housing Unit }\end{array}$ \\
\hline First Year & 6.84 & 0.95 & $1.44 \mathrm{E}-06$ & $1.37 \mathrm{E}-06$ \\
\hline Lifetime & 149.99 & 20.80 & $1.44 \mathrm{E}-06$ & $3.00 \mathrm{E}-05$ \\
\hline
\end{tabular}

\subsection{ELECTRICITY}

The estimate of the emissions rates for particulate matter for electricity is based on reported data in the 2008 National Emissions Inventory. ${ }^{46}$ The inventory furnishes quantities of PM 2.5 emitted by electric generation for each state and fuel sector. We used the EPA eGRID data ${ }^{47}$ to calculate plant-level nonbaseload generation as described in the eGRID technical support document. ${ }^{48}$ These data were combined with the National Emissions Inventory data to calculate average PM 2.5 emission rates from non-baseload generation for each NERC region.

This method yielded emission rates for PM 2.5 per kWh generated at the source. We adjusted the kWh savings from the WAP evaluation to account for transmission losses. These estimates are provided in the EPA eGRID summary tables. ${ }^{49}$

Table 6.3 shows how avoided emissions were computed for one state studied in the WAP evaluation. The calculation for the representative state shows that the average projected savings per unit in the first program year would be $678 \mathrm{kWh}$ and the avoided emissions per unit would be $6.22 \times 10^{-5}$ short tons. The projected lifetime savings would be $7,874 \mathrm{kWh}$ and the lifetime avoided emissions would be $6.13 \times 10^{-4}$ short tons.

\footnotetext{
${ }^{43}$ AP42, Compilation of Air Pollution Emission Factors, Volume 1: Stationary Point and Area Sources, Chapter 1: External Combustion Sources. http://www.epa.gov/ttnchie1/ap42/ch01/ Section 1.3 Fuel Oil Combustion Final Section - Supplement E September 1999, corrected May 2010. http://www.epa.gov/ttn/chief/ap42/ch01/final/c01s03.pdf, page 1.3-12.

44 29. N. F. Suprenant, et al., Emissions Assessment Of Conventional Stationary Combustion Systems, Volume I: Gas And Oil Fired Residential Heating Sources, EPA-600/7-79-029b, U. S. Environmental Protection Agency, Washington, DC, May 1979.

${ }^{45}$ The savings per housing unit for any state is the projected aggregate fuel oil savings from housing units with fuel oil main heat divided by the total number of housing units served by the program in that state.

${ }^{46} 2008$ National Emissions Inventory Version 3, updated March 2013. Environmental Protection Agency. http://www.epa.gov/ttnchie1/net/2008inventory.html

${ }^{47}$ EPA eGRID2012 Version 1.0 Year 2009, updated May 2012. Environmental Protection Agency. Data files downloaded from http://www.epa.gov/cleanenergy/energy-resources/eGRID/index.html

${ }^{48}$ EPA eGRID2012 Version 1.0 Year 2009 Technical Support Document. Environmental Protection Agency. Washington, D.C. Page 18-19. April 2012.

${ }^{49}$ EPA eGRID2012 Version 1.0 Year 2009 Summary Tables. Environmental Protection Agency. Washington D.C. April, 2012. Pages $7 \& 9$.
} 
Note that the installed measures vary in terms of their estimated lifetime. For measures that affect electricity, the lifetime varies between 7 years for lighting and 25 years for insulation. So, the average savings per unit are lower in some of the later years.

The NRC observed that emission rates of PM 2.5 from power plants are expected to decline over time due to increased regulation and costs. The report recommended explicitly accounting for those expected reductions in emissions and provided estimates of 2030 emissions reductions varying by pollutant and power plant fuel. ${ }^{50}$ We chose to apply a rough estimate of a $50 \%$ emissions reduction over the analysis period of 2013 to 2037. This translates to an annual reduction of $2.85 \%$ to the rate of PM 2.5 emissions from electricity generation in our models.

Table 6.3 Avoided Emissions for PM 2.5 Electricity Usage Reductions - Representative State

\begin{tabular}{|l|c|c|c|c|c|}
\hline Year & $\begin{array}{c}\text { Savings per } \\
\text { Housing Unit } \\
\text { (kWh Site) }\end{array}$ & $\begin{array}{c}\text { Savings per } \\
\text { Housing Unit } \\
\text { (kWh Source) }\end{array}$ & $\begin{array}{c}\text { Savings per } \\
\text { Housing Unit } \\
\text { (MMBtu } \\
\text { Source) }\end{array}$ & $\begin{array}{c}\text { Rate (Short } \\
\text { Tons/MMBtu) }\end{array}$ & $\begin{array}{c}\text { Short Tons per } \\
\text { Housing Unit }\end{array}$ \\
\hline 2013 & 678 & 720 & 2.46 & $2.53 \mathrm{E}-05$ & $2.53 \mathrm{E}-05$ \\
\hline 2014 & 678 & 720 & 2.46 & $2.46 \mathrm{E}-05$ & $2.46 \mathrm{E}-05$ \\
\hline 2015 & 678 & 720 & 2.46 & $2.39 \mathrm{E}-05$ & $2.39 \mathrm{E}-05$ \\
\hline 2016 & 678 & 720 & 2.46 & $2.32 \mathrm{E}-05$ & $2.32 \mathrm{E}-05$ \\
\hline 2017 & 678 & 720 & 2.46 & $2.26 \mathrm{E}-05$ & $2.25 \mathrm{E}-05$ \\
\hline First five years & 3,391 & 3,600 & 12.28 & $2.39 \mathrm{E}-05$ & $1.19 \mathrm{E}-04$ \\
\hline Lifetime & 7,874 & 8,361 & 28.53 & $2.15 \mathrm{E}-05$ & $3.44 \mathrm{E}-04$ \\
\hline
\end{tabular}

\subsection{ESTIMATING THE VALUE OF AVOIDED PARTICULATE MATTER EMISSIONS (STATE-LEVEL)}

The NRC report uses the APEEP provided by Muller et al. $(2009)^{51}$ to estimate the damages of one additional short ton of criteria air pollutants at the county level. The APEEP model differentiates between damages from ground-level emissions, such as emissions from fuel oil and natural gas heaters, and damages from point-source emissions, such as emissions from electric plants.

APPRISE contracted with the model developer to update the model with 2008 data. The 2008 countylevel damage estimates of each additional short ton of ground-level PM 2.5 were weighted by the county population counts from the 2010 census to estimate the average damage values for each state. The state damage estimates for ground-level emissions were used to calculate the benefit of avoided emissions from natural gas, propane, and fuel oil.

Damage estimates of each additional short ton of point-source PM 2.5 emissions were calculated for each NERC region. The EPA eGRID data were used to estimate the annual non-baseload electricity generation for each county using procedures described in the eGRID technical support document. ${ }^{52}$ The county-

\footnotetext{
${ }^{50}$ National Research Council 2010 Hidden Costs of Energy: Unpriced Consequences of Energy Production and Use. National Academy Press, pages 108 and 124.

${ }^{51}$ Muller, N.Z., and R.O. Mendelsohn. 2006. The Air Pollution Emission and Policy Analysis Model (APEEP). Yale University, New Haven, CT. December 2006 [online].

${ }^{52}$ The Emissions \& Generation Resource Integrated Database for 2012 (eGRID2012) Technical Support Document. Environmental Protection Agency. Washington D.C. April, 2012, page 18.
} 
level damage estimates for point-source emissions were weighted by the county-level quantity of annual non-baseload electricity generation to generate averages for each NERC region. For each state, the benefit of avoided emissions from electricity was calculated using the damage estimate for point-source emissions for the NERC region in which the majority of each state's population resides.

The NRC estimated an increase in damages per ton of pollution of approximately $50 \%$ by 2030 due to growth in population combined with increases in the value of a statistical life and other health impact values. ${ }^{53}$ We have applied a similar assumption to our models by incorporating an increase of $1.71 \%$ per year to damage values for $\mathrm{SO}_{2}, \mathrm{NO}_{\mathrm{X}}, \mathrm{PM} 2.5$, and VOC emissions.

Table 6.4 shows cost statistics in a representative state for the target analysis period - 2013 through 2037 - in nominal dollars and 2013 dollars (i.e., discounted by the recommended real discount rate furnished by $\mathrm{OMB}){ }^{54}$

Table 6.4 Social Cost of PM 2.5 (\$ per short ton) By Year (Nominal and 2013 Dollars) - Representative State

\begin{tabular}{|l|c|c|c|c|}
\hline \multirow{2}{*}{ Year } & \multicolumn{2}{|c|}{ Point-Source Emissions } & \multicolumn{2}{c|}{ Ground-Level Emissions } \\
\cline { 2 - 5 } & $\begin{array}{c}\text { \$ Per Short } \\
\text { Ton (Nominal } \\
\text { Value) }\end{array}$ & $\begin{array}{c}\text { \$ Per Short } \\
\text { Ton (2013 } \\
\text { Dollars) }\end{array}$ & $\begin{array}{c}\text { \$ Per Short } \\
\text { Ton (Nominal } \\
\text { Value) }\end{array}$ & $\begin{array}{c}\text { \$ Per Short } \\
\text { Ton (2013 } \\
\text { Dollars) }\end{array}$ \\
\hline 2013 & $\$ 51,270$ & $\$ 51,270$ & $\$ 455,079$ & $\$ 455,079$ \\
\hline 2014 & $\$ 52,147$ & $\$ 50,628$ & $\$ 462,861$ & $\$ 449,380$ \\
\hline 2015 & $\$ 53,038$ & $\$ 49,994$ & $\$ 470,776$ & $\$ 443,751$ \\
\hline 2016 & $\$ 53,945$ & $\$ 49,368$ & $\$ 478,826$ & $\$ 438,194$ \\
\hline 2017 & $\$ 54,868$ & $\$ 48,749$ & $\$ 487,014$ & $\$ 432,706$ \\
\hline Average for first five years & $\$ 53,002$ & $\$ 50,038$ & $\$ 470,911$ & $\$ 443,822$ \\
\hline Average for analysis period & $\$ 56,941$ & $\$ 47,612$ & $\$ 546,718$ & $\$ 400,270$ \\
\hline
\end{tabular}

For a representative state, the avoided emissions per housing unit are listed in Tables 6.1-6.3. The total avoided emissions per housing unit for electricity is multiplied by the dollars per short ton in 2013 dollars for point-source emissions. The total avoided emissions per housing unit for natural gas, propane, and fuel oil is multiplied by the dollars per short ton in 2013 dollars for ground-level emissions. The pointsource and ground-level emissions benefits are combined to estimate the total avoided emission benefit per unit at the state level. Table 6.5 shows that calculation for a representative state. The aggregate emissions benefit for the state is estimated using the average per unit times the number of units served. Table 6.6 shows the calculation for a representative state.

\footnotetext{
${ }^{53}$ National Research Council 2010 Hidden Costs of Energy: Unpriced Consequences of Energy Production and Use. National Academy Press, page 108.

${ }^{54}$ Jeffrey D. Zients M-13-04 Memorandum for the Heads of Departments and Agencies. Executive Office of Management and Budget. January 24, 2013.
} 
Table 6.5 Quantity and Value of Avoided Emissions for PM 2.5 Value per Unit by Fuel Type and Year (2013 Dollars) - Representative State

\begin{tabular}{|l|c|c|c|c|c|c|c|c|}
\hline \multirow{2}{*}{ Year } & Natural Gas/Propane & \multicolumn{2}{|c|}{ Fuel Oil } & \multicolumn{2}{c|}{ Electricity } & \multicolumn{2}{c|}{ All Fuels } \\
\cline { 2 - 9 } & $\begin{array}{c}\text { Short Tons } \\
\text { per Unit }\end{array}$ & $\begin{array}{c}\$ \text { per } \\
\text { Unit }\end{array}$ & $\begin{array}{c}\text { Thort } \\
\text { Tons per } \\
\text { Unit }\end{array}$ & $\begin{array}{c}\text { \$ per } \\
\text { Unit }\end{array}$ & $\begin{array}{c}\text { Short } \\
\text { Tons per } \\
\text { Unit }\end{array}$ & $\begin{array}{c}\text { \$ per } \\
\text { Unit }\end{array}$ & $\begin{array}{c}\text { Short } \\
\text { Tons per } \\
\text { Unit }\end{array}$ & $\begin{array}{c}\text { \$ per } \\
\text { Unit }\end{array}$ \\
\hline 2013 & $1.10 \mathrm{E}-05$ & $\$ 0.87$ & $1.37 \mathrm{E}-06$ & $\$ 0.11$ & $6.22 \mathrm{E}-05$ & $\$ 1.21$ & $7.45 \mathrm{E}-05$ & $\$ 2.19$ \\
\hline 2014 & $1.10 \mathrm{E}-05$ & $\$ 0.86$ & $1.37 \mathrm{E}-06$ & $\$ 0.11$ & $6.04 \mathrm{E}-05$ & $\$ 1.16$ & $7.28 \mathrm{E}-05$ & $\$ 2.13$ \\
\hline 2015 & $1.10 \mathrm{E}-05$ & $\$ 0.85$ & $1.37 \mathrm{E}-06$ & $\$ 0.11$ & $5.87 \mathrm{E}-05$ & $\$ 1.11$ & $7.11 \mathrm{E}-05$ & $\$ 2.07$ \\
\hline 2016 & $1.10 \mathrm{E}-05$ & $\$ 0.84$ & $1.37 \mathrm{E}-06$ & $\$ 0.10$ & $5.70 \mathrm{E}-05$ & $\$ 1.07$ & $6.94 \mathrm{E}-05$ & $\$ 2.01$ \\
\hline 2017 & $1.10 \mathrm{E}-05$ & $\$ 0.83$ & $1.37 \mathrm{E}-06$ & $\$ 0.10$ & $5.54 \mathrm{E}-05$ & $\$ 1.02$ & $6.78 \mathrm{E}-05$ & $\$ 1.96$ \\
\hline First five years & $5.49 \mathrm{E}-05$ & $\$ 4.26$ & $6.84 \mathrm{E}-06$ & $\$ 0.53$ & $2.94 \mathrm{E}-04$ & $\$ 5.57$ & $3.56 \mathrm{E}-04$ & $\$ 10.36$ \\
\hline Lifetime & $2.35 \mathrm{E}-04$ & $\$ 16.42$ & $3.00 \mathrm{E}-05$ & $\$ 2.09$ & $6.13 \mathrm{E}-04$ & $\$ 11.15$ & $8.78 \mathrm{E}-04$ & $\$ 29.67$ \\
\hline
\end{tabular}

Table 6.6 Quantity and Value of Avoided Emissions for PM 2.5 Aggregate Value - Representative State

\begin{tabular}{|c|c|c|c|c|c|}
\hline Year & $\begin{array}{c}\text { Housing } \\
\text { Units }\end{array}$ & $\begin{array}{c}\text { Short Tons } \\
\text { Per Unit (All } \\
\text { Fuels) }\end{array}$ & $\begin{array}{l}\text { Aggregate } \\
\text { Short Tons }\end{array}$ & $\begin{array}{c}\text { Value per } \\
\text { Unit (2013 } \\
\text { Dollars - All } \\
\text { Fuels) }\end{array}$ & $\begin{array}{c}\text { Aggregate } \\
\text { Value (2013 } \\
\text { Dollars - All } \\
\text { Fuels) }\end{array}$ \\
\hline 2013 & 14,417 & 7.45E-05 & 1.0747 & $\$ 2.19$ & $\$ 31,568$ \\
\hline 2014 & 14,417 & 7.28E-05 & 1.0492 & $\$ 2.13$ & $\$ 30,682$ \\
\hline 2015 & 14,417 & 7.11E-05 & 1.0244 & $\$ 2.07$ & $\$ 29,828$ \\
\hline 2016 & 14,417 & $6.94 \mathrm{E}-05$ & 1.0002 & $\$ 2.01$ & $\$ 29,003$ \\
\hline 2017 & 14,417 & $6.78 \mathrm{E}-05$ & 0.9768 & $\$ 1.96$ & $\$ 28,207$ \\
\hline First five years & 14,417 & $3.56 \mathrm{E}-04$ & 5.1253 & $\$ 10.36$ & $\$ 149,288$ \\
\hline Lifetime & 14,417 & $8.78 \mathrm{E}-04$ & 12.6649 & $\$ 29.67$ & $\$ 427,706$ \\
\hline
\end{tabular}




\subsection{NATIONAL TOTALS}

The state-level analysis furnishes information on the aggregate avoided emissions, the aggregate emissions benefit, and the number of units served for each state. Those are cumulated to develop a national aggregate value of avoided emissions. Table 6.7 shows the quantity of avoided emissions by fuel type. Table 6.8 shows the value of avoided emissions by fuel type. The analysis shows that if the 2010 WAP program were implemented in 2013, it would be expected to reduce PM 2.5 emissions by 403.64 short tons (Table 6.7) at a lifetime value of $\$ 22,401,066$ (Table 6.8). Most of the avoided emissions accrue from the reductions in the use of electricity.

Table 6.7 Quantity of Avoided Emissions for PM 2.5 National Aggregate Total by Fuel Type and Year

\begin{tabular}{|l|c|c|c|c|}
\hline \multirow{2}{*}{ Year } & \multicolumn{3}{|c|}{ Avoided Emissions (Short Tons of PM 2.5) } \\
\cline { 2 - 5 } & $\begin{array}{c}\text { Natural } \\
\text { Gas/Propane }\end{array}$ & Fuel Oil & Electricity & All Fuels \\
\hline 2013 & 2.42 & 0.72 & 29.85 & 32.99 \\
\hline 2014 & 2.42 & 0.72 & 29.00 & 32.14 \\
\hline 2015 & 2.42 & 0.72 & 28.17 & 31.31 \\
\hline 2016 & 2.42 & 0.72 & 27.37 & 30.51 \\
\hline 2017 & 2.42 & 0.72 & 26.59 & 29.73 \\
\hline First five years & 12.11 & 3.58 & 140.99 & 156.68 \\
\hline Lifetime & 50.63 & 14.94 & 338.07 & 403.64 \\
\hline
\end{tabular}

Table 6.8 Value of Avoided Emissions for PM 2.5 National Aggregate Total by Fuel Type and Year

\begin{tabular}{|l|c|c|c|c|}
\hline \multirow{2}{*}{ Year } & \multicolumn{3}{|c|}{ Avoided Emissions (2013 Dollars) } \\
\cline { 2 - 5 } & $\begin{array}{c}\text { Natural } \\
\text { Gas/Propane }\end{array}$ & Fuel Oil & Electricity & All Fuels \\
\hline 2013 & $\$ 385,219$ & $\$ 156,441$ & $\$ 1,221,662$ & $\$ 1,763,322$ \\
\hline 2014 & $\$ 380,395$ & $\$ 154,481$ & $\$ 1,171,980$ & $\$ 1,706,856$ \\
\hline 2015 & $\$ 375,630$ & $\$ 152,547$ & $\$ 1,124,319$ & $\$ 1,652,496$ \\
\hline 2016 & $\$ 370,926$ & $\$ 150,636$ & $\$ 1,078,596$ & $\$ 1,600,158$ \\
\hline 2017 & $\$ 366,280$ & $\$ 148,749$ & $\$ 1,034,732$ & $\$ 1,549,762$ \\
\hline First five years & $\$ 1,878,451$ & $\$ 762,854$ & $\$ 5,631,288$ & $\$ 8,272,593$ \\
\hline Lifetime & $\$ 7,045,088$ & $\$ 2,793,680$ & $\$ 12,562,298$ & $\$ 22,401,066$ \\
\hline
\end{tabular}


Table 6.9 shows the calculation for the average amount of avoided emissions and the average value per housing unit served by the WAP program. The estimated avoided emissions per housing unit at the national level is 0.001216 short tons with a lifetime value of $\$ 67.50$.

Table 6.9 Quantity and Value of Avoided Emissions for PM 2.5 Per Housing Unit - National

\begin{tabular}{|c|c|c|c|c|c|}
\hline Year & Units & $\begin{array}{l}\text { Aggregate } \\
\text { Short Tons }\end{array}$ & $\begin{array}{c}\text { Short Tons } \\
\text { Per Unit (All } \\
\text { Fuels) }\end{array}$ & $\begin{array}{c}\text { Aggregate } \\
\text { Value (2013 } \\
\text { Dollars - All } \\
\text { Fuels) }\end{array}$ & $\begin{array}{c}\text { Value Per } \\
\text { Housing Unit } \\
\text { (2013 Dollars } \\
\text { - All Fuels) }\end{array}$ \\
\hline 2013 & 331,866 & 32.99 & 0.000099 & $\$ 1,763,322$ & $\$ 5.31$ \\
\hline 2014 & 331,866 & 32.14 & 0.000097 & $\$ 1,706,856$ & $\$ 5.14$ \\
\hline 2015 & 331,866 & 31.31 & 0.000094 & $\$ 1,652,496$ & $\$ 4.98$ \\
\hline 2016 & 331,866 & 30.51 & 0.000092 & $\$ 1,600,158$ & $\$ 4.82$ \\
\hline 2017 & 331,866 & 29.73 & 0.000090 & $\$ 1,549,762$ & $\$ 4.67$ \\
\hline First five years & 331,866 & 156.68 & 0.000472 & $\$ 8,272,593$ & $\$ 24.93$ \\
\hline Lifetime & 331,866 & 403.64 & 0.001216 & $\$ 22,401,066$ & $\$ 67.50$ \\
\hline
\end{tabular}





\section{BENEFITS FROM VOC EMISSIONS REDUCTIONS}

The estimates of avoided VOC are made separately for natural gas and propane, fuel oil, and electricity. Each type of fuel has a different amount of avoided VOC per unit of energy savings. In addition, for electricity, the amount of avoided VOC varies by geographic region because of differences in the VOC emissions rates for generation plants.

\subsection{NATURAL GAS AND PROPANE}

The EPA furnished an estimate of the VOC emissions factor from natural gas combustion in boilers and furnaces in AP-42. ${ }^{55}$ Emissions are estimated to be 5.5 pounds of VOC per $10^{6}$ standard cubic feet of natural gas $\left(2.68 \times 10^{-6}\right.$ short tons per MMBtu).

Table 7.1 shows how avoided emissions were computed for one state studied in the WAP evaluation. The calculation for the representative state shows that the average projected savings per unit in the first program year would be 54.82 therms and the avoided emissions per unit would be $1.47 \times 10^{-5}$ short tons. The projected lifetime savings would be 1,152.74 therms and the lifetime avoided emissions would be $3.09 \times 10^{-4}$ short tons.

Note that the installed measures vary in terms of their estimated lifetime. For measures that affect natural gas and propane usage, the lifetime varies between 13 years for a setback thermostat to 25 years for insulation. So, the average therms of savings per unit are lower in some of the later years.

Table 7.1 Avoided Emissions for VOC Natural Gas and Propane Usage Reductions - Representative State

\begin{tabular}{|l|c|c|c|c|}
\hline Year & $\begin{array}{c}\text { Savings per } \\
\text { Housing Unit } \\
\text { (therms) }\end{array}$ & $\begin{array}{c}\text { Savings per } \\
\text { Housing Unit } \\
\text { (MMBtu) }\end{array}$ & $\begin{array}{c}\text { Rate (Short } \\
\text { Tons/MMBtu) }\end{array}$ & $\begin{array}{c}\text { Short Tons per } \\
\text { Housing Unit }\end{array}$ \\
\hline First Year & 118.56 & 11.86 & $2.68 \mathrm{E}-06$ & $3.18 \mathrm{E}-05$ \\
\hline Lifetime & $2,535.80$ & 253.58 & $2.68 \mathrm{E}-06$ & $6.80 \mathrm{E}-04$ \\
\hline
\end{tabular}

For this calculation, it was assumed that the greenhouse gas emission rates for propane were the same as the rates for natural gas. While that is likely to be a reliable assumption for combustion, it is possible that the process for producing propane has different upstream emissions. However, since propane is a small part of the total energy savings associated with the program (12.4\% of savings in the example state), the potential bias is small.

\subsection{FUEL OIL}

The fuel oil VOC emissions rate was computed using the EPA estimated VOC emissions factors from AP- $42^{57}$, Compilation of Air Pollutant Emissions. ${ }^{58}$ The EPA provided individual emissions factors from

\footnotetext{
${ }^{55}$ AP 42, Fifth Edition, Compilation of Air Pollutant Emission Factors, Volume 1: Stationary Point and Area Sources, Chapter 1: External Combustion Sources. http://www.epa.gov/ttnchie1/ap42/ch01/ 1.4 Natural Gas Combustion Final Section - Supplement D, July 1998. http://www.epa.gov/ttn/chief/ap42/ch01/final/c01s04.pdf page 1.4-6.

${ }^{56}$ The savings per housing unit for any state is the projected aggregate natural gas and propane savings from housing units that use one of those fuels divided by the total number of housing units served by the program in that state.

${ }^{57}$ AP42, Compilation of Air Pollution Emission Factors, Volume 1: Stationary Point and Area Sources, Chapter 1: External Combustion Sources. http://www.epa.gov/ttnchie1/ap42/ch01/ Section 1.3 Fuel Oil Combustion Final Section - Supplement E September 1999, corrected May 2010. http://www.epa.gov/ttn/chief/ap42/ch01/final/c01s03.pdf, page 1.3-21.
} 
fuel oil combustion for 21 speciated organic compounds. These were aggregated to get total VOC emissions for fuel oil estimated at $1.48 \times 10^{-7}$ short tons per MMBtu.

Table 7.2 shows how avoided emissions were computed for one state studied in the WAP evaluation. The calculation for the representative state shows that the average projected savings per unit in the first program year would be 6.04 gallons and the avoided emissions per unit would be $1.24 \times 10^{-7}$ short tons. The projected lifetime savings would be 127.46 gallons and the lifetime avoided emissions would be 2.61 x $10^{-6}$ short tons.

Note that the installed measures vary in terms of their estimated lifetime. For measures that affect fuel oil, the lifetime varies between 13 years for a setback thermostat to 25 years for insulation. So, the average savings per unit are lower in some of the later years.

Table 7.2 Avoided Emissions for VOC Fuel Oil Usage Reductions - Representative State

\begin{tabular}{|l|c|c|c|c|}
\hline Year & $\begin{array}{c}\text { Savings per } \\
\text { Housing Unit } \\
\text { (Gallons) }\end{array}$ & $\begin{array}{c}\text { Savings per } \\
\text { Housing Unit } \\
\text { (MMBtu) }\end{array}$ & $\begin{array}{c}\text { Rate (Short } \\
\text { Tons/MMBtu) }\end{array}$ & $\begin{array}{c}\text { Short Tons per } \\
\text { Housing Unit }\end{array}$ \\
\hline First Year & 6.84 & 0.95 & $1.48 \mathrm{E}-07$ & $1.40 \mathrm{E}-07$ \\
\hline Lifetime & 149.99 & 20.80 & $1.48 \mathrm{E}-07$ & $3.08 \mathrm{E}-06$ \\
\hline
\end{tabular}

\subsection{ELECTRICITY}

The estimate of the emissions rates for volatile organic compounds for electricity is based on reported data in the 2008 National Emissions Inventory. ${ }^{60}$ The inventory furnishes quantities of VOC emitted by electric generation for each state and fuel sector. We used the EPA eGRID data ${ }^{61}$ to calculate plant-level non-baseload generation as described in the eGRID technical support document. ${ }^{62}$ These data were combined with the National Emissions Inventory data to calculate average PM 2.5 emission rates from non-baseload generation for each NERC region.

This method yielded emission rates for VOC per kWh generated at the source. We adjusted the kWh savings from the WAP evaluation to account for transmission losses. These estimates are provided in the EPA eGRID summary tables. ${ }^{63}$

Table 7.3 shows how avoided emissions were computed for one state studied in the WAP evaluation. The calculation for the representative state shows that the average projected savings per unit in the first program year would be $1,346 \mathrm{kWh}$ and the avoided emissions per unit would be $1.53 \times 10^{-5}$ short tons. The projected lifetime savings would be $23,281 \mathrm{kWh}$ and the lifetime avoided emissions would be $2.65 \mathrm{x}$ $10^{-4}$ short tons.

\footnotetext{
58 29. N. F. Suprenant, et al., Emissions Assessment Of Conventional Stationary Combustion Systems, Volume I: Gas And Oil Fired Residential Heating Sources, EPA-600/7-79-029b, U. S. Environmental Protection Agency, Washington, DC, May 1979.

${ }^{59}$ The savings per housing unit for any state is the projected aggregate fuel oil savings from housing units with fuel oil main heat divided by the total number of housing units served by the program in that state.

${ }^{60} 2008$ National Emissions Inventory Version 3, updated March 2013. Environmental Protection Agency. http://www.epa.gov/ttnchie1/net/2008inventory.html

${ }^{61}$ EPA eGRID2012 Version 1.0 Year 2009, updated May 2012. Environmental Protection Agency. Data files downloaded from http://www.epa.gov/cleanenergy/energy-resources/eGRID/index.html

${ }^{62}$ EPA eGRID2012 Version 1.0 Year 2009 Technical Support Document. Environmental Protection Agency. Washington, D.C. Page 18-19. April 2012.

${ }^{63}$ EPA e GRID2012 Version 1.0 Year 2009 Summary Tables. Environmental Protection Agency. Washington D.C. April, 2012. Pages $7 \& 9$.
} 
Note that the installed measures vary in terms of their estimated lifetime. For measures that affect electricity, the lifetime varies between 7 years for lighting and 25 years for insulation. So, the average savings per unit are lower in some of the later years. 
Table 7.3 Avoided Emissions for VOC Electricity Usage Reductions - Representative State

\begin{tabular}{|l|c|c|c|c|c|}
\hline Year & $\begin{array}{c}\text { Savings per } \\
\text { Housing Unit } \\
\text { (kWh Site) }\end{array}$ & $\begin{array}{c}\text { Savings per } \\
\text { Housing Unit } \\
\text { (kWh Source) }\end{array}$ & $\begin{array}{c}\text { Savings per } \\
\text { Housing Unit } \\
\text { (MMBtu } \\
\text { Source) }\end{array}$ & $\begin{array}{c}\text { Rate (Short } \\
\text { Tons/MMBtu) }\end{array}$ & $\begin{array}{c}\text { Short Tons per } \\
\text { Housing Unit }\end{array}$ \\
\hline 2013 & 678 & 720 & 2.46 & $6.43 \mathrm{E}-06$ & $1.58 \mathrm{E}-05$ \\
\hline 2014 & 678 & 720 & 2.46 & $6.43 \mathrm{E}-06$ & $1.58 \mathrm{E}-05$ \\
\hline 2015 & 678 & 720 & 2.46 & $6.43 \mathrm{E}-06$ & $1.58 \mathrm{E}-05$ \\
\hline 2016 & 678 & 720 & 2.46 & $6.43 \mathrm{E}-06$ & $1.58 \mathrm{E}-05$ \\
\hline 2017 & 678 & 720 & 2.46 & $6.43 \mathrm{E}-06$ & $1.58 \mathrm{E}-05$ \\
\hline First five years & 3,391 & 3,600 & 12.28 & $6.43 \mathrm{E}-06$ & $7.89 \mathrm{E}-05$ \\
\hline Lifetime & 7,874 & 8,361 & 28.53 & $6.43 \mathrm{E}-06$ & $1.83 \mathrm{E}-04$ \\
\hline
\end{tabular}

\subsection{ESTIMATING THE VALUE OF AVOIDED VOLATILE ORGANIC COMPOUNDS EMISSIONS (STATE-LEVEL)}

The NRC report uses the APEEP provided by Muller et al. $(2009)^{64}$ to estimate the damages of one additional short ton of criteria air pollutants at the county level. The APEEP model differentiates between damages from ground-level emissions, such as emissions from fuel oil and natural gas heaters, and damages from point-source emissions, such as emissions from electric plants.

APPRISE contracted with the model developer to update the model with 2008 data. The 2008 countylevel damage estimates of each additional short ton of ground-level VOC were weighted by the county population counts from the 2010 census to estimate the average damage values for each state. The state damage estimates for ground-level emissions were used to calculate the benefit of avoided emissions from natural gas, propane, and fuel oil.

Damage estimates of each additional short ton of point-source VOC emissions were calculated for each NERC region. The EPA eGRID data were used to estimate the annual non-baseload electricity generation for each county using procedures described in the eGRID technical support document. ${ }^{65}$ The countylevel damage estimates for point-source emissions were weighted by the county-level quantity of annual non-baseload electricity generation to generate averages for each NERC region. For each state, the benefit of avoided emissions from electricity was calculated using the damage estimate for point-source emissions for the NERC region in which the majority of each state's population resides.

The NRC estimated an increase in damages per ton of pollution of approximately $50 \%$ by 2030 due to growth in population combined with increases in the value of a statistical life and other health impact values. ${ }^{66}$ We have applied a similar assumption to our models by incorporating an increase of $1.71 \%$ per year to damage values for $\mathrm{SO}_{2}, \mathrm{NO}_{\mathrm{X}}, \mathrm{PM} 2.5$, and VOC emissions.

\footnotetext{
${ }^{64}$ Muller, N.Z., and R.O. Mendelsohn. 2006. The Air Pollution Emission and Policy Analysis Model (APEEP). Yale University, New Haven, CT. December 2006 [online].

${ }^{65}$ The Emissions \& Generation Resource Integrated Database for 2012 (eGRID2012) Technical Support Document. Environmental Protection Agency. Washington D.C. April, 2012, page 18.

${ }^{66}$ National Research Council 2010 Hidden Costs of Energy: Unpriced Consequences of Energy Production and Use. National Academy Press, page 108.
} 
Table 7.4 shows cost statistics in a representative state for the target analysis period - 2013 through 2037 - in nominal dollars and 2013 dollars (i.e., discounted by the recommended real discount rate furnished by $\mathrm{OMB}){ }^{67}$

Table 7.4 Social Cost of VOC (\$ per short ton) By Year (Nominal and 2013 Dollars) - Representative State

\begin{tabular}{|l|c|c|c|c|}
\hline \multirow{2}{*}{ Year } & \multicolumn{2}{|c|}{ Point-Source Emissions } & \multicolumn{2}{c|}{ Ground-Level Emissions } \\
\cline { 2 - 5 } & $\begin{array}{c}\text { \$ Per Short } \\
\text { Ton (Nominal } \\
\text { Value) }\end{array}$ & $\begin{array}{c}\text { \$Per Short } \\
\text { Ton (2013 } \\
\text { Dollars) }\end{array}$ & $\begin{array}{c}\text { \$ Per Short } \\
\text { Ton (Nominal } \\
\text { Value) }\end{array}$ & $\begin{array}{c}\text { \$ Per Short } \\
\text { Ton (2013 } \\
\text { Dollars) }\end{array}$ \\
\hline 2013 & $\$ 4,901$ & $\$ 4,901$ & $\$ 42,908$ & $\$ 42,908$ \\
\hline 2014 & $\$ 4,985$ & $\$ 4,840$ & $\$ 43,642$ & $\$ 42,371$ \\
\hline 2015 & $\$ 5,071$ & $\$ 4,779$ & $\$ 44,388$ & $\$ 41,840$ \\
\hline 2016 & $\$ 5,157$ & $\$ 4,720$ & $\$ 45,147$ & $\$ 41,316$ \\
\hline 2017 & $\$ 5,245$ & $\$ 4,660$ & $\$ 45,919$ & $\$ 40,799$ \\
\hline Average for first five years & $\$ 5,072$ & $\$ 4,780$ & $\$ 44,401$ & $\$ 41,847$ \\
\hline Average for analysis period & $\$ 5,505$ & $\$ 4,516$ & $\$ 51,508$ & $\$ 37,760$ \\
\hline
\end{tabular}

For a representative state, the avoided emissions per housing unit are listed in Tables 7.1-7.3. The total avoided emissions per housing unit for electricity is multiplied by the dollars per short ton in 2013 dollars for point-source emissions. The total avoided emissions per housing unit for natural gas, propane, and fuel oil is multiplied by the dollars per short ton in 2013 dollars for ground-level emissions. The pointsource and ground-level emissions benefits are combined to estimate the total avoided emission benefit per unit at the state level. Table 7.5 shows that calculation for a representative state. The aggregate emissions benefit for the state is estimated using the average per unit times the number of units served. Table 7.6 shows the calculation for a representative state.

\footnotetext{
${ }^{67}$ Jeffrey D. Zients M-13-04 Memorandum for the Heads of Departments and Agencies. Executive Office of Management and Budget. January 24, 2013.
} 
Table 7.5 Quantity and Value of Avoided Emissions for VOC Value per Unit by Fuel Type and Year (2013 Dollars) - Representative State

\begin{tabular}{|l|c|c|c|c|c|c|c|c|}
\hline \multirow{2}{*}{} & \multicolumn{2}{|c|}{$\begin{array}{c}\text { Natural } \\
\text { Gas/Propane }\end{array}$} & \multicolumn{2}{c|}{ Fuel Oil } & \multicolumn{2}{c|}{ Electricity } & \multicolumn{2}{c|}{ All Fuels } \\
\cline { 2 - 10 } Year & $\begin{array}{c}\text { Short } \\
\text { Tons per } \\
\text { Unit }\end{array}$ & $\begin{array}{c}\text { \$ per } \\
\text { Unit }\end{array}$ & $\begin{array}{c}\text { Short } \\
\text { Tons per } \\
\text { Unit }\end{array}$ & $\begin{array}{c}\text { \$ per } \\
\text { Unit }\end{array}$ & $\begin{array}{c}\text { Short } \\
\text { Tons per } \\
\text { Unit }\end{array}$ & $\begin{array}{c}\text { \$ per } \\
\text { Unit }\end{array}$ & $\begin{array}{c}\text { Short } \\
\text { Tons per } \\
\text { Unit }\end{array}$ & $\begin{array}{c}\text { \$ per } \\
\text { Unit }\end{array}$ \\
\hline 2013 & $3.18 \mathrm{E}-05$ & $\$ 0.241$ & $1.40 \mathrm{E}-07$ & $\$ 0.001$ & $1.58 \mathrm{E}-05$ & $\$ 0.029$ & $4.77 \mathrm{E}-05$ & $\$ 0.27$ \\
\hline 2014 & $3.18 \mathrm{E}-05$ & $\$ 0.238$ & $1.40 \mathrm{E}-07$ & $\$ 0.001$ & $1.58 \mathrm{E}-05$ & $\$ 0.029$ & $4.77 \mathrm{E}-05$ & $\$ 0.27$ \\
\hline 2015 & $3.18 \mathrm{E}-05$ & $\$ 0.235$ & $1.40 \mathrm{E}-07$ & $\$ 0.001$ & $1.58 \mathrm{E}-05$ & $\$ 0.029$ & $4.77 \mathrm{E}-05$ & $\$ 0.26$ \\
\hline 2016 & $3.18 \mathrm{E}-05$ & $\$ 0.232$ & $1.40 \mathrm{E}-07$ & $\$ 0.001$ & $1.58 \mathrm{E}-05$ & $\$ 0.028$ & $4.77 \mathrm{E}-05$ & $\$ 0.26$ \\
\hline 2017 & $3.18 \mathrm{E}-05$ & $\$ 0.229$ & $1.40 \mathrm{E}-07$ & $\$ 0.001$ & $1.58 \mathrm{E}-05$ & $\$ 0.028$ & $4.77 \mathrm{E}-05$ & $\$ 0.26$ \\
\hline First five years & $1.59 \mathrm{E}-04$ & $\$ 1.176$ & $7.01 \mathrm{E}-07$ & $\$ 0.005$ & $7.89 \mathrm{E}-05$ & $\$ 0.144$ & $2.39 \mathrm{E}-04$ & $\$ 1.32$ \\
\hline Lifetime & $6.80 \mathrm{E}-04$ & $\$ 4.539$ & $3.08 \mathrm{E}-06$ & $\$ 0.020$ & $1.83 \mathrm{E}-04$ & $\$ 0.318$ & $8.67 \mathrm{E}-04$ & $\$ 4.88$ \\
\hline
\end{tabular}

Table 7.6 Quantity and Value of Avoided Emissions for VOC Aggregate Value - Representative State

\begin{tabular}{|l|c|c|c|c|c|}
\hline & Housing & $\begin{array}{c}\text { Short Tons } \\
\text { Per Unit (All } \\
\text { Fuels) }\end{array}$ & $\begin{array}{c}\text { Aggregate } \\
\text { Short Tons }\end{array}$ & $\begin{array}{c}\text { Value per } \\
\text { Unit (2013 } \\
\text { Dollars - All } \\
\text { Fuels) }\end{array}$ & $\begin{array}{c}\text { Aggregate } \\
\text { Value (2013 } \\
\text { Dollars - All } \\
\text { Fuels) }\end{array}$ \\
\hline 2013 & 14,417 & $4.77 \mathrm{E}-05$ & 0.69 & $\$ 0.27$ & $\$ 3,916$ \\
\hline 2014 & 14,417 & $4.77 \mathrm{E}-05$ & 0.69 & $\$ 0.27$ & $\$ 3,867$ \\
\hline 2015 & 14,417 & $4.77 \mathrm{E}-05$ & 0.69 & $\$ 0.26$ & $\$ 3,819$ \\
\hline 2016 & 14,417 & $4.77 \mathrm{E}-05$ & 0.69 & $\$ 0.26$ & $\$ 3,771$ \\
\hline 2017 & 14,417 & $4.77 \mathrm{E}-05$ & 0.69 & $\$ 0.26$ & $\$ 3,724$ \\
\hline First five years & 14,417 & $2.39 \mathrm{E}-04$ & 3.44 & $\$ 1.32$ & $\$ 19,097$ \\
\hline Lifetime & 14,417 & $8.67 \mathrm{E}-04$ & 12.50 & $\$ 4.88$ & $\$ 70,312$ \\
\hline
\end{tabular}

\subsection{NATIONAL TOTALS}

The state-level analysis furnishes information on the aggregate avoided emissions, the aggregate emissions benefit, and the number of units served for each state. Those are cumulated to develop a national aggregate value of avoided emissions. Table 7.7 shows the quantity of avoided emissions by fuel type. Table 7.8 shows the value of avoided emissions by fuel type. The analysis shows that if the 2010 WAP program were implemented in 2013, it would be expected to reduce VOC emissions by 65.34 short tons (Table 7.7) at a lifetime value of $\$ 647,474$ (Table 7.8). Most of the avoided emissions accrue from the reductions in the use of fuel oil and electricity. 
Table 7.7 Quantity of Avoided Emissions for VOC National Aggregate Total by Fuel Type and Year

\begin{tabular}{|l|c|c|c|c|}
\hline \multirow{2}{*}{ Year } & \multicolumn{3}{|c|}{ Avoided Emissions (Short Tons of VOC) } \\
\cline { 2 - 5 } & $\begin{array}{c}\text { Natural } \\
\text { Gas/Propane }\end{array}$ & Fuel Oil & Electricity & All Fuels \\
\hline 2013 & 7.01 & 0.07 & 4.77 & 11.85 \\
\hline 2014 & 7.01 & 0.07 & 4.77 & 11.85 \\
\hline 2015 & 7.01 & 0.07 & 4.77 & 11.85 \\
\hline 2016 & 7.01 & 0.07 & 4.77 & 11.85 \\
\hline 2017 & 7.01 & 0.07 & 4.77 & 11.85 \\
\hline First five years & 35.06 & 0.37 & 23.83 & 59.25 \\
\hline Lifetime & 146.55 & 1.53 & 67.59 & 215.67 \\
\hline
\end{tabular}

Table 7.8 Value of Avoided Emissions for VOC National Aggregate Total by Fuel Type and Year

\begin{tabular}{|l|c|c|c|c|}
\hline \multirow{2}{*}{ Year } & \multicolumn{3}{|c|}{ Avoided Emissions (2013 Dollars) } \\
\cline { 2 - 5 } & $\begin{array}{c}\text { Natural } \\
\text { Gas/Propane }\end{array}$ & Fuel Oil & Electricity & All Fuels \\
\hline 2013 & $\$ 105,698$ & $\$ 1,512$ & $\$ 15,363$ & $\$ 122,573$ \\
\hline 2014 & $\$ 104,374$ & $\$ 1,493$ & $\$ 15,171$ & $\$ 121,038$ \\
\hline 2015 & $\$ 103,067$ & $\$ 1,475$ & $\$ 14,981$ & $\$ 119,522$ \\
\hline 2016 & $\$ 101,776$ & $\$ 1,456$ & $\$ 14,793$ & $\$ 118,025$ \\
\hline 2017 & $\$ 100,501$ & $\$ 1,438$ & $\$ 14,608$ & $\$ 116,547$ \\
\hline First five years & $\$ 515,416$ & $\$ 7,375$ & $\$ 74,916$ & $\$ 597,707$ \\
\hline Lifetime & $\$ 1,933,351$ & $\$ 27,017$ & $\$ 196,431$ & $\$ 2,156,799$ \\
\hline
\end{tabular}

Table 7.9 shows the calculation for the average amount of avoided emissions and the average value per housing unit served by the WAP program. The estimated avoided emissions per housing unit at the national level is 0.000760 short tons with a lifetime value of $\$ 7.53$. 
Table 7.9 Quantity and Value of Avoided Emissions for VOC Per Housing Unit - National

\begin{tabular}{|l|c|c|c|c|c|}
\hline & Units & $\begin{array}{c}\text { Aggregate } \\
\text { Short Tons }\end{array}$ & $\begin{array}{c}\text { Short Tons } \\
\text { Per Unit (All } \\
\text { Fuels) }\end{array}$ & $\begin{array}{c}\text { Aggregate } \\
\text { Value (2013 } \\
\text { Dollars - All } \\
\text { Fuels) }\end{array}$ & $\begin{array}{c}\text { Value Per } \\
\text { Housing Unit } \\
(2013 \text { Dollars } \\
- \text { All Fuels) }\end{array}$ \\
\hline 2013 & 331,866 & 11.85 & 0.000036 & $\$ 122,573$ & $\$ 0.37$ \\
\hline 2014 & 331,866 & 11.85 & 0.000036 & $\$ 121,038$ & $\$ 0.36$ \\
\hline 2015 & 331,866 & 11.85 & 0.000036 & $\$ 119,522$ & $\$ 0.36$ \\
\hline 2016 & 331,866 & 11.85 & 0.000036 & $\$ 118,025$ & $\$ 0.36$ \\
\hline 2017 & 331,866 & 11.85 & 0.000036 & $\$ 116,547$ & $\$ 0.35$ \\
\hline First five years & 331,866 & 59.25 & 0.000179 & $\$ 597,707$ & $\$ 1.80$ \\
\hline Lifetime & 331,866 & 215.67 & 0.000650 & $\$ 2,156,799$ & $\$ 6.50$ \\
\hline
\end{tabular}




\section{SUMMARY OF ENVIRONMENTAL BENEFITS}

Table 8.1 furnishes information on the 2010 WAP program emissions impacts, both in tons of avoided emissions and in the estimated social value of emissions. The table shows that the aggregate value of avoided emissions is over $\$ 645$ million and that the average value per housing unit is $\$ 1,944$. SO2 emissions and $\mathrm{CO} 2$ equivalents account for almost 90 percent of the benefits. The other emissions represent a little over 10 percent of the aggregate value.

Table 8.1 Quantity and Value of Avoided Emissions by Type of Emissions Aggregate and Per Housing Unit National

\begin{tabular}{|c|c|c|c|c|c|}
\hline Type of Emissions & $\begin{array}{c}\text { Housing } \\
\text { Units }\end{array}$ & $\begin{array}{c}\text { Aggregate } \\
\text { Tons }\end{array}$ & $\begin{array}{c}\text { Tons Per } \\
\text { Unit (All } \\
\text { Fuels) }\end{array}$ & $\begin{array}{c}\text { Aggregate } \\
\text { Value (2013 } \\
\text { Dollars - All } \\
\text { Fuels) }\end{array}$ & $\begin{array}{l}\text { Value Per } \\
\text { Housing Unit } \\
\text { (2013 Dollars } \\
\text { - All Fuels) }\end{array}$ \\
\hline $\mathrm{CO}_{2}$ Equivalents & \multirow{6}{*}{331,866} & $7,382,524 *$ & 22.25 & $\$ 281,573,912$ & $\$ 848$ \\
\hline $\mathrm{SO}_{2}$ & & $10,531 * *$ & 0.0317 & $\$ 286,819,004$ & $\$ 864$ \\
\hline NOx & & $5,834 * *$ & 0.0176 & $\$ 52,179,316$ & $\$ 157$ \\
\hline PM 2.5 & & $404 * *$ & 0.001216 & $\$ 22,401,066$ & $\$ 68$ \\
\hline VOCs & & $216 * *$ & 0.000650 & $\$ 2,156,799$ & $\$ 7$ \\
\hline TOTAL & & N/A & N/A & $\$ 645,130,097$ & $\$ 1,944$ \\
\hline
\end{tabular}

${ }^{*}$ Metric Tons

${ }^{* *}$ Short Tons

Table 8.2 shows how each fuel contributes to the aggregate value of savings for each type of emissions. Natural gas and propane account for about 27 percent of the value of avoided emissions, fuel oil accounts for about 25 percent, and electricity accounts for about 48 percent.

Housing units with fuel oil main heat account for about 10 percent of WAP housing units. However, they represent about one-fourth of the benefits of avoided emissions for a number of reasons. Fuel oil has higher $\mathrm{SO}_{2}$ emissions per MMBtu than other fuels, is a ground source pollutant (i.e., is emitted at the level where it has the greatest health impact), and is emitted in areas where the social cost is highest.

Natural gas and propane account for the social cost of about 45 percent of greenhouse gas emissions (i.e., $\mathrm{CO}_{2}$ equivalents), two-thirds of $\mathrm{NO}_{\mathrm{x}}$ emissions, and almost 90 percent of the VOC emissions. About 60 percent of housing units treated by the WAP program are heated by natural gas or propane.

Electricity generation accounts for a significant share of all of the listed emissions, except for VOCs. Electricity accounts for over 50 percent of the value of avoided PM 2.5 emissions, 45 percent of the value of avoided emissions of $\mathrm{CO}_{2}$ equivalents, and 55 percent of value of avoided emissions of $\mathrm{SO}_{2}$. About 30 percent of homes treated by the WAP program use electricity as their main heating fuel. 
Table 8.2 Value of Avoided Emissions by Type of Emissions and Fuel Type Aggregate Value - National

\begin{tabular}{|l|c|c|c|c|}
\hline Type of Emissions & $\begin{array}{c}\text { Natural Gas and } \\
\text { Propane }\end{array}$ & Fuel Oil & Electricity & $\begin{array}{c}\text { Aggregate Value } \\
\text { - All Fuels }\end{array}$ \\
\hline $\mathrm{CO}_{2}$ Equivalents & $\$ 127,664,107$ & $\$ 28,409,661$ & $\$ 125,500,144$ & $\$ 281,573,912$ \\
\hline $\mathrm{SO}_{2}$ & $\$ 703,590$ & $\$ 126,795,909$ & $\$ 159,319,505$ & $\$ 286,819,004$ \\
\hline $\mathrm{NOx}$ & $\$ 34,459,893$ & $\$ 5,491,416$ & $\$ 12,228,007$ & $\$ 52,179,316$ \\
\hline PM 2.5 & $\$ 7,045,088$ & $\$ 2,793,680$ & $\$ 12,562,298$ & $\$ 22,401,066$ \\
\hline VOCs & $\$ 1,933,351$ & $\$ 27,017$ & $\$ 196,431$ & $\$ 2,156,799$ \\
\hline TOTAL & $\$ 171,806,029$ & $\$ 163,517,683$ & $\$ 309,806,385$ & $\$ 645,130,097$ \\
\hline
\end{tabular}

